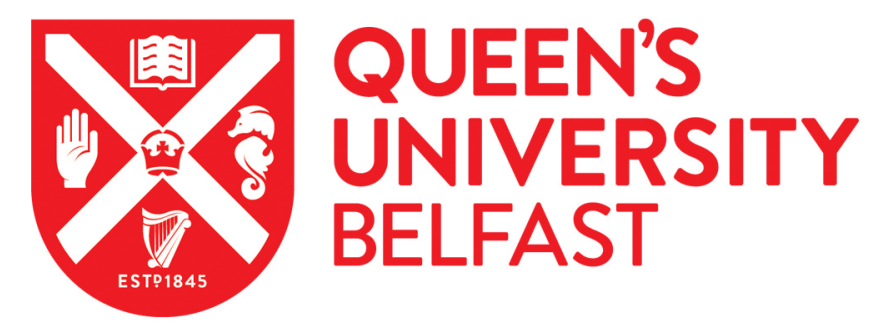

\title{
Hydrological fluctuations modulate phototrophic responses to nutrient fertilization in a large and shallow lake of Southwest China
}

Hu, K., Chen, G., Gregory-Eaves, I., Huang, L., Chen, X., Liu, Y., \& Leavitt, P. R. (2019). Hydrological

fluctuations modulate phototrophic responses to nutrient fertilization in a large and shallow lake of Southwest China. Aquatic Sciences, 81(2), [37]. https://doi.org/10.1007/s00027-019-0633-4

Published in:

Aquatic Sciences

Document Version:

Peer reviewed version

Queen's University Belfast - Research Portal:

Link to publication record in Queen's University Belfast Research Portal

Publisher rights

(C) Springer Nature Switzerland AG 2019. This work is made available online in accordance with the publisher's policies. Please refer to any applicable terms of use of the publisher.

\section{General rights}

Copyright for the publications made accessible via the Queen's University Belfast Research Portal is retained by the author(s) and / or other copyright owners and it is a condition of accessing these publications that users recognise and abide by the legal requirements associated with these rights.

Take down policy

The Research Portal is Queen's institutional repository that provides access to Queen's research output. Every effort has been made to ensure that content in the Research Portal does not infringe any person's rights, or applicable UK laws. If you discover content in the Research Portal that you believe breaches copyright or violates any law, please contact openaccess@qub.ac.uk. 
1

2

3

1 Hydrological fluctuations modulate phototrophic responses to nutrient fertilization in a

2 large and shallow lake of Southwest China

4 Kui Hu${ }^{1}$, Guangjie Chen ${ }^{1, *}$, Irene Gregory-Eaves ${ }^{2}$, Linpei Huang ${ }^{1}$, Xiaolin Chen ${ }^{1}$, Yuanyuan Liu,

$5 \quad$ Peter R. Leavitt ${ }^{3,4}$

6

$7 \quad{ }^{1}$ Yunnan Key Laboratory of Plateau Geographical Processes and Environment Change, School of

8 Tourism and Geography, Yunnan Normal University, Kunming 650500, China

$9 \quad{ }^{2}$ Department of Biology, McGill University, Montreal, Quebec H3A 1B1, Canada

$10{ }^{3}$ Institute of Environmental Change and Society, University of Regina, 3737 Wascana Parkway,

11 Regina, SK S4S 0A2, Canada

$12{ }^{4}$ Institute for Global Food Security, Queen's University Belfast, Belfast, County Antrim, United

13 Kingdom

14

15

16

17 *Email: guangjiechen@gmail.com, Tel: (+86) 13658805128 
Abstract

Lake nutrient budgets and hydrology are being altered by human activities and climate change,

21 yet little is known of how fertilization and hydrologic mechanisms interact to structure 22 assemblages of primary producers. Here, we present sediment records from a large shallow lake 23 in Southwest China to separate the relative importance of nutrients and hydrological fluctuation 24 in regulating the abundance and composition of primary producers during the $20^{\text {th }}$ century, with a 25 focus on their differential effects on diatoms and cyanobacteria. Shifts in sedimentary particle26 size distribution were consistent with the documented events of hydrological regulation during 27 1953-1971 and subsequent changes in water level associated with severe droughts. Nutrient enrichment since $\sim 1965$ resulted in a significant increase in the abundance of total phototrophs 29 (pheophytin $a, \beta$-carotene) as inferred from pigment analyses, with stronger responses of 30 cyanobacteria (echinenone, zeaxanthin) over siliceous algae (diatoxanthin). Fossil diatom 31 assemblages revealed a pronounced replacement of benthic taxa by eutrophic and planktonic 32 species (e.g., Fragilaria crotonensis) since $\sim 1973$, but we observed a significant increase of 33 small benthic Fragilaria sensu lato taxa following 2005 , which generally corresponded with a 34 moderate increase in fossil pigments. Although eutrophication was the paramount predictor of 35 changes in phototrophs during the last century, variation in lake hydrology due to climate and 36 water management also modulated phototroph abundances and, more recently, diatom 37 assemblages. Specifically, our sediment evidence suggests that hydrological fluctuation has 38 overridden fertilization by nutrients in structuring diatom composition, leading to a 39 heterogeneous response of cyanobacteria and diatoms to external forcing of this shallow lake.

41 Keywords: Yilong Lake; pigments; diatoms; eutrophication; water regulation; extreme drought 


\section{Introduction}

Lake phytoplankton and phytobenthos are known to be sensitive to environmental fluctuations such as climate change (Carvalho and Kirika, 2003) and nutrient fertilization (Jeppesen et al., 2005; Schindler, 2006). However, the relative importance of individual environmental controls may vary among basins, depending on algal identity and lake characteristics. For example, global warming can enhance phytoplankton production as temperature can directly affect algal photosynthesis and growth rate (Reynolds, 2006; Jöhnk et al., 2008). Prokaryotes, such as cyanobacteria, can be selectively promoted because their optimum growth rates occur at higher temperatures than do those of diatoms and other eukaryotic algae (Paerl and Huisman, 2008). Recent studies show that nutrient enrichment can also lead to a disproportional increase in the production of harmful algae when compared to other phytoplankton (Taranu et al., 2015), reflecting their competitive ability at high nutrient concentration (Tilman, 1987; Sterner and Elser, 2002). Furthermore, increased water-column stability due to atmospheric warming can enhance the production of harmful filamentous cyanobacteria in deep lakes (Huisman et al., 2005; Posch et al., 2012). However, nutrient fertilization can overwhelm climate control of algal production in shallow lakes (Taranu et al., 2012). Therefore, algal identity and lake typology should be considered in evaluating the strength of lake warming and eutrophication in driving primary producers (Vogt et al., 2018).

Shallow lakes are vulnerable to changes in climate and water influx due to their low volume and short water residence time when compared to deep lakes (Scheffer, 1998; Søndergaard et al., 2003). During the last few decades, anthropogenic regulation of water fluxes has been identified as a significant stressor for freshwaters in populous areas (Yang and Lu, 2014), with a decline in lake water levels often stimulating algal production and favoring phytobenthos in shallow 
65 systems (Scheffer, 1998). At the same time, climate warming has increased the occurrence of

66 extreme hydrologic events (e.g., droughts) at regional and global scales (Dai, 2011; IPCC,

67 2013), augmenting the decline of water level and ecological health (Lake, 2011). In comparison,

68 nutrient fertilization usually enhances phytoplankton production at the expense of benthic taxa

69 such as diatoms (Vadeboncoeur et al., 2003). In principle, changes in lake level and nutrient

70 influx could drive algal abundance and community composition in different directions in

71 shallow lakes that are subject to multiple stressors. Furthermore, there may exist strong

72 interactions between nutrient dynamics and hydrologic fluctuation, as prolonged water retention

73 time due to impoundment can lead to an increased level of nutrients (Maavara et al., 2015) and

74 accelerate eutrophication in shallow lakes (Chen et al., 2013). To date, little is known of how

75 such hydrologic fluctuations in shallow lakes may interact with eutrophication in regulating the

76 abundance and composition of primary producers over time.

77 In many lakes, analysis of sedimentary records can provide a reliable temporal perspective

78 on limnological responses to anthropogenic disturbances and climate change (Adrian et al.,

79 2009; Battarbee, 2010; Smol, 2010). Fossil pigments and diatoms are two widely used

80 paleolimnological indicators of algal abundance and community composition (Leavitt and

81 Hodgson, 2001; Stoermer and Smol, 2001). For example, sediment pigments have recorded the 82 independent effects of both nutrient fertilization and climate (Hall and Leavitt, 1999; Leavitt et 83 al., 2006; Bunting et al., 2007), as have fossil diatom assemblages (Smol et al., 2005; Rühland 84 et al., 2008). Diatoms from shallow lakes were found to be sensitive to lake-level changes 85 through their response to habitat quantity and quality (Brugam et al., 1998), while shifts in the 86 vertical zonation of algae with lake depth have been identified from fossil pigments 87 (Cuddington and Leavitt, 1999; McGowan et al., 2005; Hambright et al., 2008). Therefore, 
88 sediment studies in shallow lakes can be applied to quantify the relative importance of multiple 89 stressors in driving algal community structure and abundance over time.

90 We conducted sediment analyses to evaluate the long-term concordance between algal 91 abundance and diatom assemblage composition in response to multiple stressors in Yilong Lake, 92 southwest China. This large and shallow lake has undergone significant catchment development, 93 hydrological regulation and extreme droughts since the 1950s (Cui and Zhai, 2006). Modern 94 survey data also show a shift in phytoplankton density from predominately diatoms to mainly 95 cyanobacteria during the last few decades (Zhao, 2013). Consequently, we predicted that both 96 nutrient enrichment and variation in lake morphology could significantly enhance the 97 production of phytoplankton over time, particularly that of cyanobacteria, while the 98 intensification of water level changes may modulate the role of nutrients in altering the 99 community structure of diatoms (i.e. an increase of phytobenthos). Combining sediment records 100 with modern survey data, we first identified the temporal trajectories of phototrophic 101 community composition, and then by applying multivariate statistics, we identified the relative 102 importance of environmental factors which influenced phototrophs over different time intervals. 103 Overall, this study provided evidence on dual effects of nutrients and hydrologic fluctuations on 104 primary producer assemblages, with fertilization accelerating the growth of cyanobacteria-rich 105 phytoplankton, while climate warming and hydrological management increased benthic diatoms 106 over the last few decades.

\section{Material and methods}

$109 \quad 2.1$ Study site

110 Yilong Lake, located in southeast part of Yunnan Province, southwest China (Fig. 1), is a 
111 large $\left(\sim 34 \mathrm{~km}^{2}\right)$ shallow system with a maximum and average water depth of $\sim 3.7 \mathrm{~m}$ and $2.9 \mathrm{~m}$,

112 respectively (Table 1). Yilong Lake is currently hyper-eutrophic with elevated concentrations of 113 total phosphorus (TP; $\sim 120 \mu \mathrm{g} / \mathrm{L})$, total nitrogen $(\mathrm{TN} ; \sim 7.7 \mathrm{mg} / \mathrm{L})$ and Chlorophyll-a (Chl- $a$; $114 \sim 215 \mu \mathrm{g} / \mathrm{L})$. The catchment is strongly influenced by Indian monsoons and experiences a mean 115 annual precipitation is $928.3 \mathrm{~mm}$, a mean annual air temperature of $\sim 18^{\circ} \mathrm{C}$ (Fig. 2) and an 116 average insolation of 2,300 hours/year (Meteorology station of Mengzi County; 117 http://cmdp.ncc.cma.gov.cn/cn/index.htm). Bedrock within the Yilong watershed is characterized 118 by limestone and sandstone due to its Karst geology. The catchment vegetation is composed 119 mainly of Yunnan pine (Pinus yunnanensis) and mixed deciduous species, with a forest cover of $120 \sim 34.2 \%$.

121 Currently, Yilong Lake is a semi-closed system, with a hydrological residence time of $\sim 2.4$ 122 years (Li et al., 2015). However, Yilong Lake has been modified by both anthropogenic and 123 climate forcing since the 1950s (Fig. 2). The main inflow of Yilong Lake is the Chenghe River, 124 located at the northwest of the basin, which flows through the largest town within the catchment, 125 Shiping (Fig.1). Lake area dynamics derived from monitoring data (Jin, 1995) and Landsat 126 satellite imagery (Wu et al., 2016) document a consistent pattern of pronounced shrinking and 127 reduced depth during 1952-1982 and 2009-2013 (Fig. 2). For example, dredging and damming of 128 the outflowing Haikou River for electricity generation led to a decline in lake level by $\sim 2 \mathrm{~m}$ from 1291952 (maximum depth $\sim 7.0 \mathrm{~m}$ ) to $1953(\sim 5.0 \mathrm{~m}$ ), and a further drop of $0.7 \mathrm{~m}$ in 1960 (Yang and $130 \mathrm{Li}, 2010)$. Lake area further reduced in 1971 with the construction of an underground tunnel for 131 lake reclamation, which lead to a decline in maximum depth from $6.0 \mathrm{~m}$ in 1970 to $4.3 \mathrm{~m}$ in late 1321971 (Fig. 2), before the tunnel was abandoned in 1978 (Cui and Zhai, 2006). With extremely 133 low precipitation, the maximum water depth in Yilong Lake had declined further to $<1 \mathrm{~m}$ in 
134 spring of 1981, and then fluctuated between 3.6-5.5 m due to climatic and anthropogenic effects, 135 including a period of extreme drought during 2008-2012 (Zhao, 2013).

136 With agricultural expansion and catchment development starting in $\sim 1955$, non-point source 137 pollution has become the dominant source of nutrient loading to the lake, despite the substantial 138 input of urban effluent (Zhao, 2013; Zhao et al., 2013). By 2007, annual TP and TN influx from 139 farmland surface runoff accounted for 59\% and 52\% of total nutrient inputs, respectively (Wang 140 and Wang, 2008). Furthermore, farming of fish within cages was initiated in 1985 and 141 experienced an accelerating growth until 1997 (Shi and Sun, 2005), after which this practice was 142 officially forbidden in Yilong Lake. During its period of operation, cage farming extensively 143 harvested aquatic vegetation within the lake to feed herbivorous grass carp (Ctenopharyngodon 144 idellus) (Chou and Xia, 1998), resulting in a rapid loss of macrophyte coverage from $95.0 \%$ in 1451982 to $27.3 \%$ in 1992 (Table 2).

$147 \quad 2.2$ Sample collection and sediment dating

148 A 34-cm sediment core was collected from Yilong Lake in July 2013 from the deep basin $149\left(23^{\circ} 39^{\prime} 53^{\prime \prime} \mathrm{N}, 102^{\circ} 36^{\prime} 15^{\prime \prime} \mathrm{E}\right)$ using a Renberg gravity corer (Fig. 1). The sediment core was 150 sectioned immediately at $0.5-\mathrm{cm}$ intervals for the top $5 \mathrm{~cm}$ and at $1-\mathrm{cm}$ intervals for depths 151 below $5 \mathrm{~cm}$. Samples were kept dark and frozen until subsampling for pigment analyses within $15224 \mathrm{~h}$. The remaining sediments were freeze-dried and stored in the dark for subsequent analyses. 153 Sediment chronology was estimated based on ${ }^{210} \mathrm{~Pb}$ activities in sediment core samples. 154 Around 3-5 g of freeze-dried sediments were used for measuring the radio-activities of ${ }^{210} \mathrm{~Pb}$ and $155{ }^{137} \mathrm{Cs}$ in each sample using a Canberra well-detector gamma spectrometer (GCW 3023). The 156 sediment chronology sequence was established with the constant rate of supply (CRS) model 
using the stratigraphic profile of unsupported ${ }^{210} \mathrm{~Pb}$ activities (Appleby, 2001).

\section{$\underline{2.3 \text { Sediment physical and geochemical analyses }}$}

Grain-size distribution of sediment samples was determined using a Mastersizer 2000 laser analyzer (Malvern Instruments Limited, Malvern, UK). Briefly, $\sim 0.3 \mathrm{~g}$ freeze-dried and disaggregated sediment from each sample was pre-treated with $10-20 \mathrm{ml}$ of $10 \% \mathrm{H}_{2} \mathrm{O}_{2}$ to remove organic matter and then heated in $10 \mathrm{ml}$ of $10 \%$ aqueous $\mathrm{HCl}$ to remove carbonates. Thereafter, $\sim 100 \mathrm{ml}$ of deionized water was added and the sample solution was kept for $24 \mathrm{~h}$ to remove acidic ions. The sample residue was dispersed with $10 \mathrm{ml}$ of $0.05 \mathrm{~mol} / \mathrm{L}\left(\mathrm{NaPO}_{3}\right)_{6}$ on an ultrasonic vibrator for 10 min prior instrumental analysis.

Organic matter (OM) content was estimated for bulk sediments using the method of loss-onignition $\left(\%, \mathrm{LOI}_{550}\right)$ at $550{ }^{\circ} \mathrm{C}$ following the standard method (Heiri et al., 2001). Stable carbon (C) and nitrogen (N) isotope analyses $\left(\delta^{13} \mathrm{C}\right.$ and $\left.\delta^{15} \mathrm{~N}\right)$ were conducted following the standard methods of Meyer (2001). Briefly, 10 mg of homogenized, dried bulk sediment was combusted in a tin capsule at $960{ }^{\circ} \mathrm{C}$ in a FLASH 2000 elemental analyzer linked to a continuous isotope ratio flow mass spectrometer (MAT-253, Thermo Scientific, USA). C and N isotope ratios are expressed as per mil (\%o) relative to Vienna Pee Dee Belemnite (VPDB) and atmospheric $\mathrm{N}_{2}$ (AIR), respectively. Relative contents of $\mathrm{C}$ and $\mathrm{N}$ (\% dry mass) and the mass ratio of carbon to nitrogen $(\mathrm{C}: \mathrm{N})$ were also measured. The analytical precision was $< \pm 0.1 \%$ for isotopic data and $< \pm 1 \%$ for elemental data, respectively.

\section{$\underline{2.4 \text { Pigment analyses }}$}

All pigments were measured following procedures described in Saulnier-Talbot et al. (2014) 
using high performance liquid chromatography (HPLC) at the Gregory-Eaves Lab of McGill University, Canada. Briefly, sediments were freeze-dried and pigments were extracted in acetone

\section{$\underline{2.5 \text { Diatom analysis }}$}

Fossil diatoms were prepared for enumeration following the standard methods of Battarbee et al. (2001). Briefly, hydrochloric acid (10\%) was added for the removal of carbonates before processing, while $30 \%$ hydrogen peroxide was added at $\sim 80{ }^{\circ} \mathrm{C}$ to remove organic material. A portion of the digested slurry was dried on cover slips and mounted with Naphrax ${ }^{\circledR}$. Diatom identification and enumeration were performed under oil immersion at 1,000× magnification 
using a Leica DM 2500 microscope with phase contrast. A minimum of 400 valves was counted

\section{$\underline{2.6 \text { Numerical methods }}$}

The major zones for the biostratigraphy were identified through the analyses of constrained incremental sum of squares (CONISS), while a broken-stick model was used to test for the significance of each break. We conducted ordination analyses to define the historical trajectories of pigment and diatom changes. Preliminary investigation with Detrended Correspondence Analysis (DCA) of pigment and diatom assemblages revealed short gradient lengths of 0.68 and 1.76 SD, respectively, indicating that pigments and diatom taxa responded in a linear fashion to environmental gradients (ter Braak and Prentice, 1988). Subsequently, Principal Components Analysis (PCA) was applied to extract the major direction of variation in both the diatom species compositions and fossil pigment assemblages. Pigment PCA used only the most chemicallystable pigments as suggested by Leavitt and Hodgson (2001) and Moorhouse et al. (2014). Redundancy Analysis (RDA) was performed subsequently to explore the relationship between biological data and nine environmental predictor variables (Hall and Leavitt, 1999; ter Braak and Šmilauer, 2002). Specifically, these environmental variables included grain size components, $\delta^{13} \mathrm{C}, \delta^{15} \mathrm{~N}, \mathrm{C}: \mathrm{N}$ ratio, total carbon and total nitrogen measured from bulk sediments (Table 3). Monte Carlo analysis with 999 permutations was used to test the significance of each predictor variable in partial RDA. Only variables with a $\mathrm{P}$-value $<0.05$ were retained for the minimum 
226 adequate model (ter Braak and Šmilauer, 2002). In addition, environmental variables with a 227 variation inflation factor (VIF) of $>20$ were excluded due to their strong co-linearity with other variables.

229 Multiple regression with forward selection and variation partitioning analysis were used to identify a minimum subset of significant explanatory variables for the time window of $\sim 1903-$ 2013 (ter Braak and Šmilauer, 2002). We also performed RDA and variation partitioning analyses for the time window of $\sim 1953-2013$, the period with the most complete meteorological 233 and catchment data, including air temperature, precipitation, wind speed, and catchment 234 population. Finally, we conducted a third variation partitioning exercise for lake-water Chl- $a$ for 235 the monitoring period 1992-2015 using six environmental variables (temperature, precipitation, 236 wind speed, TP, TN and lake area) to predict recent changes in water quality. In all cases, we 237 transformed environmental predictor time series for normalization and square-root transformed 238 diatom relative abundance data with rare species down-weighted (Lepš and Šmilauer, 2003). All 239 the data analyses were performed using the $\mathrm{R}$ packages vegan (Oksanen et al., 2015) and rioja 240 (Juggins, 2015).

\section{Results}

$243 \quad \underline{3.1 \text { Archived data }}$

244 Meteorological data generally show a warming trajectory with marked variation in 245 precipitation during the last six decades. The annual mean temperature shows a warming trend, 246 increasing from an average $( \pm \mathrm{SD})$ of $18.5 \pm 0.3{ }^{\circ} \mathrm{C}$ during $1951-1990$ to a mean of $19.2 \pm 0.6{ }^{\circ} \mathrm{C}$ 247 for the last two decades (Fig. 2a). The annual precipitation displays no clear trend since 1951, but 248 shows reduced values $(<600 \mathrm{~mm})$ during the intervals of 1961-1962, 1979-1980, 1987-1989, 
2004-2005 and 2010-2012. Annual wind speed (Fig. 2b) is relatively stable during 1951-1995 ( $3.4 \pm 0.3 \mathrm{~m} / \mathrm{s}$ ), but declines to $2.3 \pm 0.3 \mathrm{~m} / \mathrm{s}$ by 2010 . Lake level and surface area both decrease over the last six decades, with abrupt drops in the mid-1950s, late-1970s and during 2009-2013 (Fig. 2c). Meanwhile, the total catchment population doubles during the last six decades (Fig. 2b).

Variables related to lake primary production and water quality indicate a substantial increase in primary producer abundance over the historical record (Fig. 2). The lake-water concentrations of TN, TP and Chl- $a$ have experienced a rapid increase concomitant with a decline in transparency from $>2 \mathrm{~m}$ to $<1 \mathrm{~m}$ during 1985-1997 (Fig. 2e) and a rapid loss of submerged aquatic vegetation (Table 2). For example, the mean concentration of measured total phosphorus (TP) and total nitrogen (TN) show an undulating pattern since late 1980s, but a clear tendency to nutrient enrichment during 2009-2012 (Fig. 2d). From the mid-1980s to the mid-1990s, TP and TN levels are elevated with a mean $( \pm \mathrm{SD})$ of $75.2 \pm 21.2 \mu \mathrm{g} / \mathrm{L}$ and $5.0 \pm 0.6 \mathrm{mg} / \mathrm{L}$, respectively. Nutrient content is relatively stable during the $2000 \mathrm{~s}(\mathrm{TP}=54.0 \mu \mathrm{g} / \mathrm{L}, \mathrm{TN}=1.8 \mathrm{mg} / \mathrm{L})$, before increasing after $\sim 2009$ (Fig. 2d). In general TP and TN increase at similar rates $(r=0.68, p<$ $0.001, \mathrm{n}=21$ ), with a $\mathrm{N}: \mathrm{P}$ mass ratio consistently above 20 (or molar ratio of 44) since 1988 (Table 2).

Monitoring data show that Chl-a values are relatively high in the mid-1990s (ca. $100 \mu \mathrm{g} / \mathrm{L}$ ), decline to minima $(<50 \mu \mathrm{g} / \mathrm{L})$ for 15 years, then increase to historical maxima $(>150 \mu \mathrm{g} / \mathrm{L})$ after 2010 (Fig. 2e). At the sample time, measured phytoplankton density increase gradually from $8.41 \times 10^{6}$ cells $/ \mathrm{L}$ in 1957 to $193.21 \times 10^{6}$ cells $/ \mathrm{L}$ in 1992 , and thereafter from $<100 \times 10^{6}$ cells $/ \mathrm{L}$ during 1993-2008 to $>200 \times 10^{6}$ cells/L after 2008 (Table 2). During this period, phytoplankton community composition gradually shifts from predominantly Bacillariophyta in 1957 to

271 Chlorophyta in 1988 and 1993, and, more recently, to Cyanobacteria (Table 2). Consistent with 
272 the fluctuation in nutrients and phytoplankton, water transparency decreases from $>1.8 \mathrm{~m}$ during 273 the early 1980 s to $<1 \mathrm{~m}$ in 2007 and then shows a swift drop from $>1 \mathrm{~m}$ in 2008-2009 to $\sim 0.2 \mathrm{~m}$ 274 since 2010 (Fig. 2e).

$276 \quad 3.2$ Sediment chronology

277 The unsupported ${ }^{210} \mathrm{~Pb}$ radioactivity profile declined with increasing core depth between 10 278 and $\sim 30 \mathrm{~cm}$ (Fig. 3a), suggesting that the ${ }^{210} \mathrm{~Pb}$-based CRS model was applicable in constructing 279 the chronological profile. Sediment samples above the $\sim 7 \mathrm{~cm}$ depth showed a uniform ${ }^{210} \mathrm{~Pb}$ 280 activity, possibly reflecting sediment mixing or variation in sediment focusing due to changes in 281 basin morphology (Fig. 2c). In lakes where mixing has occurred, the ${ }^{210} \mathrm{~Pb}$ dates covering 10 282 year accumulation, as is the case for this sediment core (Fig. 3b), often provide a maximum error 283 of less than 2 years (Appleby, 2001). Increased autochthonous production which would dilute the 284 atmospheric ${ }^{210} \mathrm{~Pb}$ fallout may also cause a decrease in its activity as observed in surface 285 sediments above $\sim 7 \mathrm{~cm}$ (Fig. 3a). The depth profile of ${ }^{137} \mathrm{Cs}$ showed no obvious peak (Fig. 3a), 286 reflecting a possible combination of sediment mixing and post-deposition mobility (e.g., Wieland 287 et al., 1993; Sommerfield and Nittrouer, 1999). Overall, radio-isotope profiles and CRS 288 calculations suggest a recent acceleration in the rate of sediment accumulation (Fig. 3b).

\section{$\underline{3.3 \text { History of lake environmental change }}$}

Grain size data showed modest changes over the length of the core (Fig. 4), with a decline in sand particles and the occurrence of abrupt fluctuations in median grain size during the last century. For example, the median size varied around a mean ( $\pm 1 \mathrm{SD})$ of $4.8 \pm 1.4 \mu \mathrm{m}$, with the 294 clay $(<2 \mu \mathrm{m})$ and sand $(>63 \mu \mathrm{m})$ components varying in the range of $7.2-30.0 \%$ (mean $=25.8 \%)$ 
295 and $0.03-7.7 \%($ mean $=1.7 \%)$, respectively. Both the silt composition and median grain size 296 spiked around the depths of $23.5,17.5,7.5$ and $3.25 \mathrm{~cm}$ (Fig. 4).

297 Stable sedimentary TN content in the early $20^{\text {th }}$ century $(3.6 \pm 0.2 \mathrm{mg} / \mathrm{g})$ gave way to an 298 increase since $\sim 1970$, with a recent mean of $6.7 \pm 0.8 \mathrm{mg} / \mathrm{g}$ (Fig. 4). The concentrations of both 299 total carbon (TC) and organic matter $\left(\mathrm{LOI}_{550}\right)$ displayed similar trajectories suggesting that lake 300 production increased after the late-1960s. The mass ratio of $\mathrm{C} / \mathrm{N}$ in bulk sediments declined from 301 historical values of $\sim 16$ to modern ratios of $\sim 11$, consistent with an increasing input of organic 302 matter derived from algae.

303 The $\delta^{15} \mathrm{~N}$ signal of bulk sediments remained stable around the near-atmospheric value $(\sim 0 \%)$ 304 until the mid-1960s, at which time it increased dramatically up to a maximum value of $\sim 4.5 \%$ in 305 surface sediments. Correspondingly, the bulk sediment $\delta^{13} \mathrm{C}$ signal declined from around $-14 \%$ 306 to nearly $-16 \%$ over the $20^{\text {th }}$ century, with a marked decline after $\sim 1960$. These relatively 307 enriched values are characteristic of lakes with high carbonate content in sediments (Jarvis et al., 308 2006), and were correlated inversely with the total algal abundance as measured by the total 309 phototroph biomarker, $\beta$-carotene $(\mathrm{r}=-0.92, \mathrm{P}<0.001)$.

\section{$311 \quad$ 3.4 Pigment variations}

312 Analysis of sedimentary pigments suggested a progressive increase in autotrophic 313 production during the 20th century with a particularly marked upturn starting in the mid-1960s 314 for most of the major taxonomic groups (Fig. 5a). The concentrations of many pigment 315 biomarkers were low and stable prior to the mid $20^{\text {th }}$ century (zone I), including chemically316 stable (pheophythin- $a, \beta$-carotene) and labile (Chl- $a$ ) indices of total phototrophic abundance, as 317 well as pigments from bloom-forming cyanobacteria (zeaxanthin, echinenone). During 1965- 
319 three-fold increase in concentrations of ubiquitous biomarkers of total phototrophic abundance

$320(\beta$-carotene, pheophythin- $a)$ and bloom-forming chlorophytes (lutein) and cyanobacteria 321 (zeaxanthin, echinenone). Fossil pigment concentrations were also generally higher after $\sim 2004$ 322 (zone III, above $\sim 8 \mathrm{~cm}$ ), as identified by the CONISS results (Fig. 5a). During this later interval, 323 the ratio of chlorophyll- $a$ /pheophytin- $a$ increased markedly, suggesting that preservation 324 conditions have been relatively constant throughout the core except for zone III (Fig. 5a). Overall, 325 historical changes in concentrations of the major pigments were highly correlated with increased 326 content of $\mathrm{TN}$, including compounds from total algae (i.e. Chl- $a ; \mathrm{r}=0.900, \mathrm{P}<0.001, \mathrm{n}=37$ ), cyanobacteria (i.e. zeaxanthin; $\mathrm{r}=0.918, \mathrm{P}<0.001$ ) and diatoms (diatoxanthin; $\mathrm{r}=0.864, \mathrm{P}<$ $0.001)$.

The Principal Components Analysis (PCA) results further revealed only one significant axis for algal abundance data, which accounted for $98.9 \%$ of the variation in biomarker assemblages (Fig. 6a). PCA axis 1 showed a significant relationship with TN $(r=0.903, P<0.001)$ during the last century. In addition, this axis was correlated significantly with sand content $(\mathrm{r}=0.226, \mathrm{P}<$ 0.01) over the last century, as well as measured air temperature $(\mathrm{r}=0.313, \mathrm{P}<0.001)$ and wind speed $(\mathrm{r}=0.406, \mathrm{P}<0.01)$ during $\sim 1953-2013$.

\section{$\underline{3.5 \text { Diatom compositional changes }}$}

A total of 62 diatom taxa were identified in sediment samples, including 23 taxa with a maximum abundance of $\geqslant 1 \%, 16$ of which occurred with a relative abundance of $\geqslant 2 \%$ in at least one sample. Diatom assemblages were composed mainly of benthic species with strong variations amongst taxa over the $20^{\text {th }}$ century (Fig. 5b). For example, Staurosira construens (a 
range of 4.2-51.0\%), S. berolinensis (6.5-44.6\%) and Achnanthidium minutissimum (0-12.1\%) all exhibited wide variation in relative abundance. Benthic diatoms were generally predominant (> $50 \%$ relative abundance) across the core except in the depths of 17.5-9.5 cm ( 1978-2000), at which time planktonic and tychoplanktonic diatoms became more important within the assemblage $(\sim 50-80 \%$ of total frustules). Planktonic diatoms mainly included Fragilaria crotonensis (1.2-52.4\%), while tychoplanktonic taxa were composed of Aulacoseira subarctica (1.6-25.1\%), A. granulata (0.7-14.7\%), and A. ambigua (1.0-8.2\%).

Similar to the pigment changes, diatom assemblages were characterized by two significant shifts (Fig. 5b). During the period of $~ 1903-1973$ (zone I), the community was composed of both benthic taxa, such as $S$. berolinensis $($ mean $=17.7 \%)$ and $S$. construens $(16.8 \%)$, and several planktonic taxa such as F. crotonensis (15.1\%) and A. subarctica (13.2\%). After $\sim 1973$ (zone II), there was a significant community shift towards more eutrophic taxa and an associated decrease in small benthic Fragilaria sensu lato taxa, coupled with an increase in F. crotonensis to over $30 \%$ and the disappearance of S. leptostauron. After 2005 (zone III), the community was characterized by the replacement of planktonic taxa such as $F$. crotonensis and Aulacoseira spp. $(<10 \%)$ by small benthic taxa such as $S$. construens and $S$. berolinensis (mean $=40.8 \%$ and $28.3 \%$, respectively).

Principal components analysis (PCA) of diatom data showed that the first two PCA axes were statistically significant based on the broken-stick model, accounting for $51.5 \%$ and $16.8 \%$ of the total variance, respectively (Fig. 6b). Planktonic species (such as F. crotonensis, A. subarctica, A. granulata) were strongly associated with the left side of axis 1 , with several benthic species such as $S$. construens and S. berolinensis sitting at the opposite end of this axis. $\mathrm{PC}$ axis 1 further showed a significant correlation with the proportion of benthic diatoms $(\mathrm{r}=$ 
$3640.953, \mathrm{P}<0.001)$, as well as the sand component $(\mathrm{r}=0.571, \mathrm{P}<0.001)$ and $\mathrm{TN}(\mathrm{r}=0.548, \mathrm{P}<$ 365 0.001). In contrast, benthic taxa such as S. pinnata and S. leptostauron were more abundant 366 during the period of 1903-1973 (zone I) and were strongly associated with PCA axis 2, which 367 itself displayed a significant correlation with TN $(r=0.606, P<0.001)$. Only PCA axis 1 showed 368 a significant relationship between diatom composition and air temperature $(r=0.658, P<0.001)$ 369 during the $\sim 1953-2013$ interval.

370

\section{$\underline{\text { 3.6 Identifying limnological drivers for algal changes }}$}

The Redundancy Analysis (RDA) suggested that nutrient and hydrological parameters played independent roles in shaping the temporal changes in primary producer assemblages of Yilong Lake (Fig. 7). The measured physio-chemical variables collectively accounted for the majority of the changes in pigments (i.e. > 90\%), but less than half of the historical variation in diatom assemblages (Table 3). Specifically, nutrients (i.e. TN) were found to be the most significant forces in driving the changes of both pigments and diatoms since $\sim 1903$. The nutrient-associated RDA axis 1 accounted for $92.0 \%$ of the total variance for pigment data but smaller amount for diatom data (42.3\%; Fig. 7). Over a shorter time window of $\sim 1953-2013$ (Table 3), nutrient variables remained as the predominant factor in driving pigment changes $(>90 \%)$ but structured diatom assemblages to a much lesser degree $(<15 \%)$. In contrast, the grain-size proxies played an insignificant role in driving both indicators over the last century; however, the sand content was identified as a significant factor over the last six decades and accounted for $\geqslant 20 \%$ of the total variance for both pigments and diatoms. Temperature also displayed a significant impact on both algal indicators since $\sim 1953$ (28.8\% and $23.3 \%$, respectively), but wind speed was found to be a major driver only for pigments (38.4\%; Table 3 ). 
The variance partitioning results further showed that lake-water TN concentration, but not response to a combination of nutrient enrichment and hydrologic fluctuation in Yilong Lake $\mathrm{TP}$, was a significant diver, accounting for $21.7 \%$ of the change in water-column Chl- $a$ for the monitoring period of 1992-2015 (Fig. 8b). Furthermore, hydrologic fluctuation inferred from changes in lake area independently explained $28.8 \%$ of the total variance in lake-water Chl- $a$, with a high proportion shared with nutrients (19.5\%) over the monitoring period. Likewise, sediment $\mathrm{TN}$ alone explained $24.6 \%$ of the total variance in sedimentary Chl- $a$, while the variation of sediment sand content alone accounted for $5.0 \%$ of the total variance in Chl- $a$ with a strong interaction with nutrients $(43.0 \%)$ during the last century (Fig. 8a).

Over the whole core, sedimentary TN collectively accounted for a large proportion of the total variance for both algal pigments and diatom assemblages (i.e. $90.0 \%$ and $40.6 \%$, respectively; Fig. 8c, e). However, the nutrient effect was found to be insignificant for diatom assemblages during 1953-2013 (Fig. 8f), whereas it accounted for the majority of the total variance in phototrophic abundance over the same time window (82.4\%; Fig. 8d). In comparison, the relative importance of hydrological fluctuation (as inferred from sand content) for diatom assemblages increased from 4.7\% (Table 3) over the core to 27.3\% during 1953-2013 (Fig. 8f), the period when temperature was also found to be a significant driver $(8.5 \%)$ and interacted moderately with hydrological fluctuation (14.8\%; Fig. 8f). From $\sim 1953$, both wind speed and hydrological fluctuation showed a strong influence on algal production, but mostly through its interaction with nutrients such as TN (i.e. $35.3 \%$ and 14.0\%, respectively; Fig. 8d).

\section{Discussion}

Our multi-proxy sedimentary records revealed a clear trajectory of phototrophic changes in 
410 during the last century. The sedimentary record of fossil pigments showed a dramatic increase 411 concomitant with nutrient enrichment, while more recent changes in production appear to

412 correspond to declining water level and wind speed. Meanwhile, the sediment records of grain 413 size (e.g. sand content and median size) documented the role of hydrological regulation and 414 extreme droughts on lake levels, which affected algal production and diatom assemblages over 415 time. Diatom community composition showed two significant shifts during the past century; with 416 a gradual replacement of oligotrophic taxa by eutrophic species since $\sim 1973$, and a distinct 417 increase in small benthic Fragilaria sensu lato taxa in after 2005 . In general, diatom 418 community composition was structured mainly by nutrient enrichment over the $20^{\text {th }}$ century, 419 although effects of hydrologic fluctuations appear to have been more pronounced in the past two 420 decades.

\section{$\underline{4.1 \text { Lake eutrophication and phototrophic responses }}$}

Our sedimentary records of lake eutrophication were highly consistent with patterns recorded from monitoring data for Yilong Lake. As the human population in the catchment began to increase in the 1960s, sediment TN values steadily increased, with a concomitant decrease in bulk sediment $\mathrm{C} / \mathrm{N}$ ratios and $\delta^{13} \mathrm{C}$ values after the 1960s (Fig. 4), patterns that are consistent with increased input of nutrients and autochthonous C sources (Meyers and Ishiwatari, 1993). For example, an annual input of 341 and 40 tons of TN and TP was estimated for the early 1990s (Chou and Xia, 1998). The archival data showed that the content of lake-water nutrients and Chl$a$ generally increased concurrent with a decline in lake-water transparency during 1985-1997 and 2009-2013 (Fig. 2). The decline of the bulk sediment carbon isotopic signal, coupled with an increase in cyanobacteria, suggested a shift of carbon source and transfer towards a planktonic 
433 pathway typical of eutrophic subtropical (Xu et al., 2014) and temperate lakes (McGowan et al., 434 2005). The rise in $\delta^{15} \mathrm{~N}$ is also consistent with the release of isotopically-enriched pollutants 435 arising from urban (Leavitt et al., 2006) and agricultural sources (Bunting et al., 2007), while the 436 depletion of $\delta^{15} \mathrm{~N}$ prior to the mid-1960s may be linked with deposition of atmospheric nitrogen 437 (Kang et al., 2019) and/or a paramount importance in fixed nitrogen within the lake (Hayes et al., 438 2019).

439 Concentrations of fossils from total algae and major algal components increased 440 dramatically from 1965 in a pattern similar to that observed in other lakes impacted by 441 agriculture (Bunting et al., 2007; Moorhouse et al., 2014) and urbanization (Leavitt et al., 2006). 442 Similar long-term increases in primary producer abundance as a result of intensified catchment 443 development have been recorded in other lakes within this study region (Wu et al., 2002; Shi and 444 Sun, 2005), as well as those from eastern China (Xu et al., 2014; Deng et al., 2016). Furthermore, 445 these changes are generally consistent with a 100-fold increase in the cell density of monitored 446 lake-water phytoplankton during the last few decades (Table 2). Similarly, monitoring programs 447 within Yilong Lake reveal that the dominant phytoplankton by cell density gradually shifted from 448 Bacillariophyta in 1957 to positively-buoyant (and more easily sampled) Cyanobacteria since 449 1997. The moderate concentration for cyanobacterial pigments, such as zeaxanthin, prior to $450 \sim 1965$ was consistent with the presence of cyanobacterial blooms of Microcystis aeruginosa in 4511957 (Ley et al., 1963).

Nutrient input also led to significant shifts in the diatom community, although effects of fertilization appear to have declined in the last decade. For example, the period of $\sim 1973-1998$ was characterized by a rapid enrichment in $\mathrm{TN}$ and the predominance of $F$. crotonensis, a planktonic species often found in nutrient-enriched lakes (Bennion et al., 2009; Hu et al., 2012). 
This taxon declined during the period of 1998-2008, when lake-water nutrients and algal production were lower (Fig. 2), and there existed a moderate drop in sediment pigment concentrations (e.g. zeaxanthin and lutein). Since $\sim 1998$, the abundance of small benthic Fragilaria sensu lato taxa increased significantly at the expense of planktonic diatoms in Yilong Lake, suggesting a decreasing role of nutrients in driving diatom community reorganization over the last decade. Finally, from the late 2000s, analyses of monitoring and sediment data suggest that cyanobacterial abundance has increased relative to that of diatoms. Similarly, increasing dominance of cyanobacteria has been well recorded in regional studies of temperate lakes under nutrient-enriched conditions (Taranu et al., 2015).

\subsection{Hydrological and climatic impacts on algae}

Analyses of sediment grain size distribution, together with archival environmental data, provide evidence for that hydrologic fluctuations served as a significant driver of phototrophic community change. Specifically, the hydrologic fluctuation inferred from changes in sediment sand content explained a large proportion of the variance in sediment Chl- $a$ pigments, while variation in lake area (another hydrological proxy) was a strong predictor of changes in lakewater Chl- $a$ concentration (Fig. 8). A moderate decrease of sediment sand content starting from the 1950 s corresponds to the documented history of hydrological regulation and decreased water levels (Cui and Zhai, 2006). Lake regulation often decreases the natural variation of water level and lake turbulence (Menking, 1997; Digerfeldt et al., 2000), resulting in a gradual decrease in the sand component over time (Wang et al., 2019). Similarly, the spikes in median grain size were synchronous with several major events of extreme drought over the last six decades (Figs. $2 \mathrm{a}$ and 4). Lake regulation can often amplify the nutrient effect and promote algae production by 
479 concentrating nutrients (Serruya and Pollingher, 1977; Peršić et al., 2007), enhancing nutrient 480 retention (Maavara et al., 2015) and reducing water turnover (Posch et al., 2012). Accordingly, 481 our results showed a pronounced increase in the content of sediment nutrient and pigment 482 concentrations starting from $\sim 1953$ (Fig. 4), as well as a significant interaction between 483 hydrologic fluctuation and nutrients (Fig. 8) at this time. These patterns are consistent with 484 earlier studies of other hydrologically-managed and drought-sensitive shallow lakes based on monitoring data (Yang and Lu, 2014) and sediment records (Chen et al., 2011).

Previous surveys show that phototrophic response to nutrient concentrations within lakes can be modulated by both warming (Vogt et al. 2018) and extreme climate (Anderson, 2000; Berthon et al., 2014). Recent warming during the last two decades has been identified as an important factor regulating diatom compositional shift in this study region (Chen et al., 2014a), as well as in many parts of the world (Winder and Hunter, 2008; Finkel et al., 2009; Rühland et al., 2015). The stability of water column can be further enhanced by a falling wind speed (i.e. $<3 \mathrm{~m} / \mathrm{s}$ ) during the last two decades, which often favors the bloom of buoyant cyanobacteria such as Microcystis in eutrophic shallow lakes (Zhang et al., 2012). The most recent drought, occurring during 2009-2012, reduced lake levels by $\sim 2.3 \mathrm{~m}$ with a loss of $\sim 0.67$ billion $\mathrm{m}^{3}$ of water (Wang et al., 2014). Meanwhile, the shift from planktonic diatoms to small benthic Fragilaria sensu lato taxa indicated the expansion of littoral taxa. This can result from warming-associated hydrodynamic change (i.e. increased evaporation; Byllaardt and Cyr, 2011), and the loss of lake volume which was caused by severe droughts and possibly amplified by elevated water use due to an increased population size (Fig. 2 and Table 2).

In 2010, the dominant Cyanobacteria (Microcystis) was replaced by Cylindrospermopsis raciborskii (Table 2), a species that can tolerate varying N:P ratios (Barica et al., 1980) as well as 
502 extreme droughts (Marc et al., 2000). Similarly, there was a clear loss of Aulacoseira spp. during 503 the last decade, a taxon which had been consistently subdominant in diatom assemblages over much of the core (Fig. 5b). Aulacoseira taxa have a high siliceous content and are known to proliferate in frequently-mixed waters that favor resuspension of these heavy taxa (Reynolds, 1987; Chen et al., 2011). This trend was synchronous with the recent decrease of wind speed, that was widely observed across China and linked with the weakening east Asian monsoon (Xu et al., 2006). Therefore, changes in lake level and thermal stability may favor specific algae in the context of regional warming (Wagner and Adrian, 2009; Romo et al., 2013).

\section{$\underline{4.3 \text { Heterogeneity in algal responses to multiple stressors }}$}

Despite pigment and diatom data exhibiting generally coherent shifts during the past 513 century (Fig. 4a, b), there exist key differences in the importance of nutrient supply to the 514 apparent production of individual photosynthetic groups. For example, the strong relationship 515 between sediment TN and cyanobacteria pigments agrees with the demonstrated ability of lakewater TN to predict cyanobacteria abundance in temperate regions (Beaulieu et al., 2014) and the positive response of primary producers to $\mathrm{N}$ influx (Leavitt et al., 2006; Bunting et al. 2007). N supply to Yilong Lake may have limited algal growth early in the $20^{\text {th }}$ century, when sedimentary $\delta^{15} \mathrm{~N}$ was low and characteristic of fixed $\mathrm{N}_{2}$ from diazotrophic cyanobacteria, and disproportionately high $\mathrm{P}$ influx occurred with agricultural development in 1960s (Shiping Yearbook, 2005), leading to a low N:P mass ratio of 12.9-14.4 (Fig. 2). Thereafter, this shallow system was characterized by a consistently high $\mathrm{N}: \mathrm{P}$ mass ratio (i.e. $>40$ ) for the past two decades (Table 2), suggesting that the content of $\mathrm{P}$, coupled with increasing $\mathrm{N}$ influx, may have impacted algal production through changing N:P ratio (Li et al., 2015). Later on, a rapid decrease 
525 of $\mathrm{N}: \mathrm{P}$ mass ratio from $>80$ to $<50$ corresponded to a shift of dominant Cyanobacteria from heterocystous diazotroph Aphanizomenon flosaquae in 1992 to non-nitrogen fixing Microcystis aeruginosa in 1997 and 2008, respectively (Table 2). This pattern suggests that non-nitrogen fixers can bloom with varying $\mathrm{N}: \mathrm{P}$ ratios when there is sufficient $\mathrm{P}$ supply, as is found in other large shallow lakes (Xie et al., 2003; Xu et al. 2010; Hayes et al., 2019).

Our comparative study highlights the increasing effects of hydrologic fluctuations and regional climate variability on variation in phototrophs over the last few decades. Noticeably, an increase in the lake-water Chl- $a$ concentration and its sediment pigment is strongly linked with hydrologic fluctuations over time (Fig. 8a, b). Even though the increased ratio of chlorophyll$a /$ pheophytin- $a$ (Fig. 5a) suggested an incomplete pigment degradation and preservation in sediments during 2004-2013, the major pigment components generally display an increasing trend of Chl- $a$ and cyanobacteria concentrations that are comparable with lake-water surveys (Fig. 2e and Table 2). Meanwhile, the benthic diatom percentage rose sharply as water column depth declined during the last two decades, despite the concurrent decline in macrophyte coverage (Table 2). The rapid rise in the cyanobacteria (zeaxanthin) pigments also suggests that there was an increase in the growth of cyanobacteria at the expense of other algae as observed in other shallow lakes (McGowan et al., 2005). Previous studies show that hydrologic fluctuation could serve as a key driver of algae in nutrient-enriched shallow lakes through increasing benthic production (Vadeboncoeur et al., 2003), or even overiding nutrients in structuring diatom composition (Liu et al., 2017). More recently, water level drops may have exposed more benthic habitats (e.g. mud and rocks) favoring small Fragilaria sensu lato taxa as is found in neighboring shallow lakes (Liu et al., 2017; Kang et al., 2019). The diatom compositional change is also broadly consistent with the finding that lake depth could play a significant role in 
548 affecting biotic responses to climate change in polymictic lakes (Chen et al., 2014b). Therefore, 549 the role of nutrients was relatively truncated in driving diatom composition with hydrologic 550 modulation and warming climate, leading to a heterogeneous pattern in the algal changes.

\section{5. Conclusion}

Our lake sediment records reveal a predominant effect of nutrient enrichment on phototrophic abundance in this shallow lake, as well as an increasing role of hydrological variability during the past few decades. Although fossil pigments appear to record a history of continuous fertilization, the replacement of eutrophic diatom species by small benthic taxa also suggests that anthropogenic water regulation, extreme droughts and warming have an influence on species composition. Such an interaction between nutrient and hydrological stressors is increasingly recognized (Vogt et al. 2018) and should be fully considered for reliable interpretation of paleoecological indicators and long-term ecosystem changes in shallow lakes. Finally, this study highlights the necessity of using multiple indicators for tracking primary production and phototrophic changes in shallow lakes. In particular, biological proxies (e.g. diatoms and pigments) have been increasingly and successfully applied in sediment-based studies to infer the temporal change of ecosystem structure in shallow systems, but they are often applied singularly without a full consideration of the differences in their sensitivity to multiple stressors for data interpretation which is evidenced in this work.

\section{$\underline{\text { Acknowledgements }}$}

This work was supported by the National Key Research and Development Program of China [grant number 2017YFA0605202], National Natural Science Foundation of China [grant number 
57141171048 , U1133601], and Ministry of Education of China [grant number 213034A]. PRL and

572 IGE were supported by the Canada Research Chair program. We are grateful to Huibin Lu and

573 Haibin Shi for their field work assistance, as well as Jiaoyuan Wang, Jianshuang Tao and

574 Wengang Kang for their constructive comments. Constructive comments provided by two

575 anonymous reviewers and editor are appreciated. 


\section{$\underline{\text { References }}$}

Adrian R, O'Reilly CM, Zagarese H, Baines SB, Hessen DO, Keller W, Livingstone DM, Sommaruga R, Straile D, Donk EV, Weyhenmeyer GA, Winder M (2009) Lakes as sentinels of climate change. Limnol Oceanogr 54:2283-2297.

Anderson JN (2000) Miniview: Diatoms, temperature and climatic change. Eur J Phycol 35:307314.

Appleby PG (2001) Chronostratigraphic techniques in recent sediments. In: Tracking environmental change using lake sediments. Volume 1: Basin analysis, coring and chronological techniques, (eds Smol JP, Birks HJB, Last WM) vol 1. Kluwer Academic Publishers, Dordrecht, The Netherlands, pp 171-203.

Barica J, Kling HJ, Gibson J (1980) Experimental Manipulation of Algal Bloom Composition by Nitrogen Addition. Can J Fish Aquat Sci 37:1175-1183.

Battarbee RW, Jones VJ, Flower RJ, Cameron NG, Bennion H (2001) Diatoms. In: Tracking Environmental Change Using Lake Sediments. Volume 3: Terrestrial, Algal, and Siliceous 590 Indicators (eds Smol JP, Birks HJB, Last WM) vol 3. Kluwer Academic Publishers, Dordrecht, 591 The Netherlands, pp 155-201.

592 Battarbee RW (2010) Foreword. In: Global Change Impacts on Mountain Lakes (eds Eggermont 593 H, Kernan M, Martens K). Hydrobiologia 648:1-2.Beaulieu M, Pick F, Palmer M, Watson S, 594 Winter J, Zurawell R, Gregory-Eaves I, Prairie Y (2014) Comparing predictive cyanobacterial 595 models from temperate regions. Can J Fish Aquat Sci 71:1830-1839.

596 Bennion H, Rawcliffe R, Clarke G, Clarke SJ, Davidson TA, Rose C, Rose N, Sayer CD, Turner 597 S (2009) Using novel palaeolimnological techniques to define lake conservation objectives. Final 598 Report to Natural England. http://discovery.ucl.ac.uk/id/eprint/399621. 
599 Berthon V, Alric B, Rimet F, Perga M-E (2014) Sensitivity and responses of diatoms to climate 600 warming in lakes heavily influenced by humans. Freshwater Biol 59:1755-1767.

601 Brugam RB, McKeever K, Kolesa L (1998) A diatom-inferred water depth reconstruction for an 602 Upper Peninsula, Michigan, lake. J Paleolimnol 20:267-276.

603 Bunting L, Leavitt PR, Gibson CE, McGee EJ (2007) Degradation of water quality in Lough 604 Neagh, Northern Ireland, by diffuse nitrogen flux from a phosphorus-rich catchment. Limnol 605 Oceanogr 52:354-369.

606 Byllaardt JV, Cyr H (2011) Does a warmer lake mean smaller benthic algae? Evidence against 607 the importance of temperature-size relationships in natural systems. Oikos 120:162-169.

608 Carvalho L, Kirika A (2003) Changes in shallow lake functioning: response to climate change 609 and nutrient reduction. Hydrobiologia 506-509:789-796.

610 Chen C, Zhao L, Zhu C, Wang J, Jiang J, Yang S (2014a) Response of diatom community in 611 Lugu Lake (Yunnan-Guizhou Plateau, China) to climate change over the past century. J 612 Paleolimnol 51:357-373.

613 Chen G, Selbie DT, Griffiths K, Sweetman JN, Botrel M, Taranu ZE, Knops S, Bondy J, 614 Michelutti N, Smol JP, Gregory-Eaves I (2014b) Proximity to ice fields and lake depth as 615 modulators of paleoclimate records: a regional study from southwest Yukon, Canada. J 616 Paleolimnol 52:185-200.

617 Chen X, Yang X, Dong X, Liu E (2013) Environmental changes in Chaohu Lake (southeast, 618 China) since the mid 20th century: The interactive impacts of nutrients, hydrology and climate. 619 Limnologica 43:10-17.

620 Chen X, Yang X, Dong X, Liu Q (2011) Nutrient dynamics linked to hydrological condition and 621 anthropogenic nutrient loading in Chaohu Lake (southeast China). Hydrobiologia 661:223-234. 
622 Chou G, Xia F (1998) Enhancing Environmental Management Promotes Water Quality in Yilong 623 Lake. Yunnan Environ Sci 17:54-56.

624 Cuddington K, Leavitt PR (1999) An individual-based model of pigment flux in lakes: 625 implications for organic biogeochemistry and paleoecology. Can J Fish Aquat Sci 56:1964-1977.

626 Cui B, Zhai H (2006) Characteristics of wetland functional degradation and its ecological water 627 requirement for restoration in Yilong Lake of Yunnan Plateau. Chinese Sci Bull 51:127-135.

628 Dai A (2011) Drought under global warming: a review. Wiley Interdisciplinary Reviews: Clim 629 Change 2:45-65.

630 Deng J, Qin B, Sarvala J, Salmaso N, Zhu G, Ventelä A-M, Zhang Y, Gao G, Nurminen L, 631 Kirkkala T, Tarvainen M, Vuorio K (2016) Phytoplankton assemblages respond differently to 632 climate warming and eutrophication: A case study from Pyhäjärvi and Taihu. J Great Lakes Res $633 \quad 42: 386-396$.

634 Digerfeldt G, Olsson S, Sandgren P (2000) Reconstruction of lake-level changes in lake Xinias, 635 central Greece, during the last 40000 years. Palaeogeogr Palaeoclimatol Palaeoecol 158:65-82.

636 Finkel ZV, Vaillancourt CJ, Irwin AJ, Reavie ED, Smol JP (2009) Environmental control of 637 diatom community size structure varies across aquatic ecosystems. Proc R Soc B 276:1627-1634. 638 Hall RI, Leavitt PR (1999) Effects of agriculture, urbanization, and climate on water quality in 639 the northern Great Plains. Limnol Oceanogr 44:739-756.

640 Hambright KD, Zohary T, Eckert W, Schwartz SS, Schelske CL, Laird KR, Leavitt PR (2008) 641 Exploitation and destabilization of a warm, freshwater ecosystem through engineered 642 hydrological change. Ecol Appl 18:1591-1603. 
643 Hayes, NM, A Patoine, HA Haig, GL Simpson, VJ Swarbrick, E Wiik, PR Leavitt (2019) Spatial 644 and temporal variation in nitrogen fixation and its importance to phytoplankton in phosphorus645 rich lakes. Freshwater Biol 64: 269-283.

646 Heiri O, Lotter F, Lemcke G (2001) Loss on ignition as a method for estimating organic and 647 carbonate content in sediments: reproducibility and comparability of results. J Paleolimnol $648 \quad 25: 101-110$.

$649 \mathrm{Hu}$ Z, Li Y, Li S (2012) Spatial and temporal distributions of diatom communities and their 650 relationships with environmental factors in Lake Erhai. J Lake Sci 24:400-408.

651 Huisman J, Matthijs HCP, Visser PM (2005) Harmful Cyanobacteria. Springer-Verlag GmbH, $652 \quad 3: 1-23$.

653 IPCC (2013) Synthesis Report. Contribution of Working Groups I, II and III to the Fourth 654 Assessment Report of the Intergovernmental Panel on Climate Change. IPCC, Geneva, 655 Switzerland.

656 Jarvis IAN, Gale AS, Jenkyns HC, Pearce MA (2006) Secular variation in Late Cretaceous 657 carbon isotopes: a new $\delta^{13} \mathrm{C}$ carbonate reference curve for the Cenomanian-Campanian (99.6658 70.6 Ma). Geol Mag 143:561-608.

659 Jeppesen E, Søndergaard M, Jensen JP, Havens KE, Anneville O, Carvalho L, Coveney M, 660 Deneke R, Dokulil MT, Foy B, Gerdeaux D, Hampton SE, Hilt S, Kangur K, Köhler J, Lammens 661 E, Lauridsen TL, Manca M, Miracle M, Moss B, Nõges P, Persson G, Phillips G, Portielje R, 662 Romo S, Schelske CL, Straile D, Tatrai I, Willén E, Winder M (2005) Lake responses to reduced 663 nutrient loading-an analysis of contemporary long-term data from 35 case studies. Freshwater 664 Biol 50:1747-1771.Jin XC (1995) China Lake Environment (Volume 3). Haiyang Publishers, 665 China, pp 263-273. 
666 Jöhnk KD, Huisman JEF, Sharples J, Sommeijer BEN, Visser PM, Stroom JM (2008) Summer

667 heatwaves promote blooms of harmful cyanobacteria. Global Change Biol 14:495-512.

668 Juggins S (2015) rioja: Analysis of Quaternary Science Data (R package version 2.0-6. CRAN.

669 R-project.org/Package $=$ rioja)

670 Kang W, Chen G, Wang J, Huang L, Wang L, Li R, Hu K, Liu Y, Tao J, Blais JM, Smol JP 671 (2019) Assessing the impact of long-term changes in climate and atmospheric deposition on a 672 shallow alpine lake from southeast Tibet. Sci Total Environ 650:713-724.

673 Krammer K, Lange-Bertalot H (1986-1991) Bacillariophyceae 1-4. In: Susswasserflora von 674 Mitteleuropa, Band 1-4 (eds Ettl H, Gerloff J, Heynig H, Mollenhauer D). Gustav Fischer Verlag, 675 Jena, Germany.

678 Leavitt PR, Hodgson DA (2001) Sedimentary pigments. In: Tracking Environmental Change 679 Using Lake Sediments. Volume 3: Terrestrial, Algal, and Siliceous Indicators (eds Smol JP, Birks 680 HJB, Last WM) vol 3. Kluwer Academic Publishers, Dordrecht, The Netherlands, pp 295-325. 681 Leavitt PR, Brock CS, Ebel C, Patoine A (2006) Landscape-scale effects of urban nitrogen on a 682 chain of freshwater lakes in central North America. Limnol Oceanogr 51:2262-2277.Lepš J, 683 Šmilauer P (2003) Multivariate analysis of ecological data using CANOCO. Cambridge 684 University Press, Cambridge, UK.

685 Ley S, Yu M, Li K, Tseng C, Chen C, Kao P, Huang F (1963) Limnological Survey of the lakes 686 of Yunnan Plateau. Oceanol ET Limnol Sinica 5:87-114.

687 Li Y, Liu Y, Zhao L, Hastings A, Guo H (2015) Exploring change of internal nutrients cycling in 688 a shallow lake: A dynamic nutrient driven phytoplankton model. Ecol Model 313:137-148. 
689 Liu Y, Chen G, Hu K, Shi H, Huang L, Chen X, Lu H, Zhao S, Chen L (2017) Biological

690 responses to recent eutrophication and hydrologic changes in Xingyun Lake, southwest China. J

691 Paleolimnol 57:343-60.

692 Maavara T, Parsons CT, Ridenour C, Stojanovic S, Durr HH, Powley HR, Van Cappellen P 693 (2015) Global phosphorus retention by river damming. Proc Natl Acad Sci USA 112:1560369415608.

695 Marc B, Falcão D, Marinho M, Pagano M, Moura A (2000) Occurrence of Cylindrospermopsis 696 (Cyanobacteria) in 39 Brazilian tropical reservoirs during the 1998 drought. Aquatic Microbial 697 Ecol 23:13-27.

698 McGowan S, Leavitt PR, Hall RI, Anderson NJ, Jeppesen E, Odgaard BV (2005) Controls of 699 algal abundance and community composition during ecosystem state change. Ecology 86:2200700 2211.Menking KM (1997) Climate signals in clay mineralogy and grain-size variations in Owens 701 Lake core OI-92, eastern California. Special Paper of the Geol. Soc Am 317:25-36.

702 Meyer TJ (2001) Sediment organic matter. In: Tracking Environmental Change Using Lake 703 Sediments. Volume 2: Physical and geochemical methods (eds Smol JP, Birks HJB, Last WM) 704 vol 3. Kluwer Academic Publishers, Dordrecht, The Netherlands, pp 239-269.

705 Meyers PA, Ishiwatari R (1993) Lacustrine organic geochemistry - an overview of indicators of 706 organic matter sources and diagenesis in lake sediments. Org Geochem 20:867-900.

707 Moorhouse HL, McGowan S, Jones MD, Barker P, Leavitt PR, Brayshaw SA, Haworth EY 708 (2014) Contrasting effects of nutrients and climate on algal communities in two lakes in the 709 Windermere catchment since the late 19th century. Freshwater Biol 59:2605-2620. 
710 Oksanen J, Blanchet FG, Kindt R, Legendre P, Min-Chin PBR, O'Hara RB, Simpson GL, 711 Solymos P, Henry M, Stevens H (2015) vegan: Community Ecology Package (R package version 712 2.0-6. CRAN. R-project.org/Package = vegan).

713 Paerl H, Huisman J (2008) Blooms like it hot. Science 320:57-58.

714 Peršić V, Horvatić J, Has-Schön E, Bogut I (2007) Changes in N and P limitation induced by 715 water level fluctuations in Nature Park Kopački Rit (Croatia): nutrient enrichment bioassay. 716 Aquat. Ecology 43:27-36.

717 Posch T, Köster O, Salcher MM, Pernthaler J (2012) Harmful filamentous cyanobacteria 718 favoured by reduced water turnover with lake warming. Nature Climate Change 2:809-813.

719 R Team (2013) R: a language and environment for statistical computing. R Foundation for 720 Statistical Computing, Vienna, Austria. ISBN 3-900051-07-0, URL http://www. R-project.org. 721 Reynolds CS (1987) The response of phytoplankton communities to changing lake 722 environments. Swiss J Hydrol 49:220-236.

723 Reynolds CS (2006) Ecology of Phytoplankton (Ecology, Biodiversity and Conservation). 724 Cambridge University Press, Cambridge, UK.

725 Romo S, Soria JM, Campo FFD, Benkaddour YO, Barón-Sola Á (2013) Water residence time 726 and the dynamics of toxic cyanobacteria. Freshwater Biol 58:513-522.

727 Round F, Crawford R, Man D (2007) The diatoms biology and morphology of the genera. 728 Cambridge University Press, Cambridge, UK.

729 Rühland K, Paterson AM, Smol JP (2008) Hemispheric-scale patterns of climate-related shifts in 730 planktonic diatoms from North American and European lakes. Global Change Biol 14:27407312754. 
732 Rühland KM, Paterson AM, Smol JP (2015) Lake diatom responses to warming: reviewing the 733 evidence. J Paleolimnol 54:1-35.

734 Saulnier-Talbot É, Gregory-Eaves I, Simpson KG, Efitre J, Nowlan TE, Taranu ZE, Chapman LJ 735 (2014) Small Changes in Climate Can Profoundly Alter the Dynamics and Ecosystem Services 736 of Tropical Crater Lakes. Plos One 9:e86561.

737 Scheffer MS, Hosper SH, Meijer ML, Moss B, Jeppesen E (1993) Alternative equilibria in 738 shallow lakes. Trends Ecol Evol 8:275-279.

739 Scheffer M (1998) Ecology of Shallow Lakes. London, UK: Chapman and Hall 740 Schindler DW (2006) Recent advances in the understanding and management of eutrophication. 741 Limnol Oceanogr 51:356-363.

742 Serruya C, Pollingher U (1977) Lowering of water level and algal biomassin Lake Kinneret. 743 Hydrobiologia 54:73-80.

744 Shi L, Sun Q (2005) Brief Talk on Effect of Aquatic Plant Purifying Water body of Yilong Lake. 745 Yunnan Environ Sci 24:40-42.

746 Shiping Yearbook (2005) Shiping Year Book (County Condification Committee). Yunnan 747 Peoples's Publishing Press, pp 56-67, 169-173.

748 Smol JP, Wolfe AP, Birks HJ, Douglas MS, Jones VJ, Korhola A, Pienitz R, Ruhland K, Sorvari 749 S, Antoniades D, Brooks SJ, Fallu MA, Hughes M, Keatley BE, Laing TE, Michelutti N, 750 Nazarova L, Nyman M, Paterson AM, Perren B, Quinlan R, Rautio M, Saulnier-Talbot E, 751 Siitonen S, Solovieva N, Weckstrom J (2005) Climate-driven regime shifts in the biological 752 communities of arctic lakes. Proc Natl Acad Sci USA 102:4397-4402.

753 Smol JP (2010) The power of the past: using sediments to track the effects of multiple stressors 754 on lake ecosystems. Freshwater Biol 55:43-59.Sommerfield C, Nittrouer C (1999) Modern 
8

755 accumulation rates and a sediment budget for the Eel shelf: a flood-dominated depositional 756 environment. Mar Geol 154:227-241.

757 Søndergaard M, Jensen JP, Jeppesen E (2003) Role of sediment and internal loading of 758 phosphorus in shallow lakes. Hydrobiologia 506:135-145.

759 Sterner R, Elser JJ (2002) Ecological Stoichiometry: The Biology of Elements From Molecules 760 to The Biosphere. Princeton University Press, pp 439.

761 Stoermer EF, Smol JP (2001) The Diatoms: Applications for the environmental and earth science.

762 Cambridge: Cambridge University Press. Cambridge: Cambridge University Press.

763 Taranu ZE, Zurawell RW, Pick F, Gregory-Eaves I (2012) Predicting cyanobacterial dynamics in 764 the face of global change: the importance of scale and environmental context. Global Change 765 Biol 18:3477-3490.

766 Taranu ZE, Gregory-Eaves I, Leavitt PR, Bunting L, Buchaca T, Catalan J, Domaizon I, 767 Guilizzoni P, Lami A, McGowan S, Moorhouse H, Morabito G, Pick FR, Stevenson MA, 768 Thompson PL, Vinebrooke RD (2015) Acceleration of cyanobacterial dominance in north 769 temperate-subarctic lakes during the Anthropocene. Ecol Lett 18:375-384.

770 ter Braak CJF, Prentice IC (1988) A theory of gradient analysis. Adv Ecol Res 18:271-313.

771 ter Braak CJF, Šmilauer P (2002) CANOCO Reference Manual and CanoDraw for Windows 772 User's Guide: Software for Canonical Community Ordination [Version 4.5]. Microcomputer 773 Power, Ithaca, NY.

774 Tilman D (1987) Resource competition and community structure. Monographs in Population 775 Biology. Princeton University Press 17:1-296. 
Vadeboncoeur Y, Jeppesen E, Zanden MJV, Schierup HH, Christoffersen K, Lodge DM (2003)

From Greenland to green lakes: Cultural eutrophication and the loss of benthic pathways in lakes. Limnol Oceanogr 48:1408-141.

Vogt RJ, Sharma S, Leavitt PR (2018) Direct and interactive effects of climate, meteorology, 780 river hydrology, and lake characteristics on water quality in productive lakes of the Canadian 781 Prairies. Can J Fish Aquat Sci 75:47-59.

782 Wagner C, Adrian R (2009) Cyanobacteria dominance: Quantifying the effects of climate chang. 783 Limnol Oceanogr 54:2460-2468.

784 Wang H, Yang Z, Wang L, Liu Y, Song Y, Gao J (2014) The application of TVDI in drought 785 monitoring over Yunnan province during 2009 to 2010. J. Yunnan University (Sci.) 36:59-65.

786 Wang J, Chen G, Kang W, Hu K, Wang L (2019) Impoundment intensity determines temporal 787 patterns of hydrological fluctuation, carbon cycling and algal succession in a dammed lake of 788 Southwest China. Water Res 148:162-75.

789 Wang W, Wang L (2008) Current situation of agricultural non-point source pollution and Control 790 Countermeasures in Yilong lake. Yunnan Agricultural Science and Technology, pp 139-141. 791 Wang Z (1997) Survey of zooplankton and fish productivity in Yilong Lake, Yunnan. J. Fisheries 792 China 402-407.

793 Wieland E, Santschi P, Höhener P, Sturm M (1993) Scavenging of Chernobyl ${ }^{137}$ Cs and natural $794{ }^{210} \mathrm{~Pb}$ in Lake Sempach, Switzerland. Geochimica Et Cosmochimica Acta 57:2959-2979.

795 Winder M, Hunter DA (2008) Temporal organization of phytoplankton communities linked to 796 physical forcing. Oecologia 156:179-192.

797 Wu F, Zheng M, Hu G (2016) The Estimation of Vegetation Coverage of Yanshan County in 798 Yunnan by Remote Sensing Based on OLI Data. Environ Sci Survey 36:5-7. 
Wu J, Jiang X, Xia W, Pan H, Yin Y (2002) Climate and Primary Productivity over the last 500 years of the Chenghai Lake,Yunnan. Mar Geol Quaternary Geol 22:95-98.

801 Xie L, Xie P, Li S, Tang H, Liu H (2003) The low TN:TP ratio, a cause or a result of Microcystis 802 blooms? Water Res 37:2073-2080.

$803 \mathrm{Xu} \mathrm{H}$, Paerl H, Qin B, Zhu G, Gao G (2010) Nitrogen and phosphorus inputs control 804 phytoplankton growth in eutrophic lake Taihu, China. Limnol Oceanogr 55:420-432.

805 Xu J, Wen Z, Ke Z, Zhang M, Zhang M, Guo N, Hansson LA, Xie P (2014) Contrasting energy 806 pathways at the community level as a consequence of regime shifts. Oecologia 175:231-241. 807 Xu M, Chang CP, Fu CB, Qi Y, Robock A, Robinson D, Zhang HM (2006) Steady decline of east 808 Asian monsoon winds, 1969-2000: Evidence from direct ground measurements of wind speed. J 809 Geophy Res 111: 1-8.

810 Yang L, Li H, (2010) Wetlands of Yunnan. China Forestry Publishing House, pp 94-101.

811 Yang X, Lu X (2014) Drastic change in China's lakes and reservoirs over the past decades. Sci $812 \operatorname{Rep} 4: 6041$.

813 Zhang J, Wang Z, Song Z, Xie Z, Li L, Song L (2012) Bioaccumulation of microcystins in two 814 freshwater gastropods from a cyanobacteria-bloom plateau lake, Lake Dianchi. Environ Pollut $815 \quad 164: 227-34$

816 Zhang Y, zhang E, Liu M (2009) Spectral absorption properties of chromophoric dissolved 817 organic matter and particulate matter in Yunnan Plateau lakes. J Lake Sci 21:255-263.

818 Zhao L (2013) The regime shifts and inversion of catastrophic driving factors in the ecosystems 819 of Yilong Lake, Yunnan. Dissertation, University of Chinese Academy of Science. 
820 Zhao L, Li Y, Zou R, He B, Zhu X, Liu Y, Wang J, Zhu Y (2013) A three-dimensional water 821 quality modeling approach for exploring the eutrophication responses to load reduction scenarios 822 in Lake Yilong (China). Environ Pollut 177:13-21. 
823 Table 1 Summary of key limnological features of Yilong Lake

\begin{tabular}{|c|c|}
\hline Variable & Value \\
\hline Altitude $(\mathrm{m})^{\mathrm{a}}$ & $1,413.4$ \\
\hline Lake surface area $\left(\mathrm{km}^{2}\right)^{\mathrm{a}}$ & 34.0 \\
\hline Catchment area $\left(\mathrm{km}^{2}\right)^{\mathrm{a}}$ & 326.0 \\
\hline Average water depth $(\mathrm{m})^{\mathrm{a}}$ & 2.9 \\
\hline Max. water depth (m) ${ }^{a}$ & 3.7 \\
\hline Chlorophyll $\left(\mu \mathrm{g} / \mathrm{l}^{\mathrm{b}}\right.$ & 214.3 \\
\hline Transparency (m) ${ }^{b}$ & 0.1 \\
\hline $\mathrm{TN}(\mathrm{mg} / \mathrm{l})^{\mathrm{b}}$ & 7.7 \\
\hline $\mathrm{TP}(\mu \mathrm{g} / \mathrm{l})^{\mathrm{b}}$ & 123.3 \\
\hline $\mathrm{pH}^{\mathrm{b}}$ & 8.8 \\
\hline
\end{tabular}

$824{ }^{\mathrm{a}}$ Data are from Yang \& $\mathrm{Li}$ (2010).

$825{ }^{b}$ Data were collected in the summer of 2013 from the current study. 
Table 2 Monitored changes of algae abundance, lake-water N:P mass ratio and macrophyte coverage over time in Yilong Lake

\begin{tabular}{|c|c|c|c|c|c|c|c|}
\hline Year & $\begin{array}{l}\text { Cyanobacteria } \\
\left(10^{6} \text { cell } / 1\right)\end{array}$ & $\begin{array}{c}\text { Diatoms } \\
\left(10^{6} \text { cell/l }\right)\end{array}$ & $\begin{array}{l}\text { Phytoplankton } \\
\left(10^{6} \text { cell } / 1\right)\end{array}$ & Dominant algae & $\begin{array}{c}\text { Cyanobacteria } \\
(\%)\end{array}$ & $\begin{array}{l}\mathrm{N}: \mathrm{P} \text { ratio } \\
\text { (by mass) }\end{array}$ & $\begin{array}{l}\text { Macrophyte } \\
\text { coverage }(\%)\end{array}$ \\
\hline 1957 & & & $8.41^{\mathrm{a}}$ & $\begin{array}{l}\text { Bacillariophyta (except episodic } \\
\text { cyanobacteria bloom in Aug.) }\end{array}$ & & & \\
\hline 1982 & & & & & & 14.39 & $95.0^{d}$ \\
\hline 1988 & & & $46.00^{\mathrm{b}}$ & $\begin{array}{c}\text { Chlorophyta } \\
\text { (Pediastrum simplex) }\end{array}$ & & 89.23 & \\
\hline 1992 & $180.47^{c}$ & $4.00^{c}$ & $193.21^{\mathrm{c}}$ & $\begin{array}{c}\text { Cyanobacteria } \\
\text { (Aphanizomenon flosaquae) }\end{array}$ & $93.41^{\mathrm{c}}$ & 82.95 & $27.3^{\mathrm{e}}$ \\
\hline 1993 & & & $50.88^{d}$ & $\begin{array}{c}\text { Chlorophyta } \\
\text { (Pediastrum simplex) }\end{array}$ & & 73.84 & \\
\hline 1997 & $19.76^{\mathrm{e}}$ & $0.21^{\mathrm{e}}$ & $21.78^{\mathrm{e}}$ & $\begin{array}{c}\text { Cyanobacteria } \\
\text { (Microcystis aeruginosa) }\end{array}$ & $90.75^{\mathrm{e}}$ & 38.28 & $40.0^{\mathrm{e}}$ \\
\hline 2008 & $82.30^{f}$ & $1.31^{\mathrm{f}}$ & $88.51^{\mathrm{f}}$ & $\begin{array}{c}\text { Cyanobacteria } \\
\text { (Microcystis aeruginosa) }\end{array}$ & $92.98^{f}$ & 49.65 & $60.0^{\mathrm{e}}$ \\
\hline 2010 & & & $317.20^{\mathrm{e}}$ & $\begin{array}{c}\text { Cyanobacteria } \\
\text { (Cylindrospermopsis raciborskii) }\end{array}$ & 99.00 & 40.33 & $<10.0^{\mathrm{e}}$ \\
\hline 2015 & 244.65 & 0.59 & 248.14 & $\begin{array}{c}\text { Cyanobacteria } \\
\text { (Aphanizomenon flosaquae) }\end{array}$ & 98.59 & 51.20 & \\
\hline
\end{tabular}


829 Table 3 Summary of individual RDAs for key environmental variables in accounting for the 830 variance (adjusted $\mathrm{R}^{2}$ ) in the algal production and diatom PC1 score during the periods of $\sim 1903$ 8312013 and $\sim 1953-2013$, respectively

\begin{tabular}{lllll}
\hline \multirow{2}{*}{ Environmental Variable } & \multicolumn{3}{c}{ Pigments } & \multicolumn{2}{c}{ Diatom PC1 } \\
& $1903-2013$ & $1953-2013$ & $1903-2013$ & $1953-2013$ \\
\hline Median grain size $(\mu \mathrm{m})$ & -0.027 & -0.034 & -0.023 & -0.024 \\
Clay $(\%)$ & -0.027 & -0.033 & -0.022 & -0.019 \\
Silt $(\%)$ & -0.024 & -0.016 & -0.016 & 0.007 \\
Sand $(\%)$ & 0.034 & $0.197 * *$ & 0.047 & $0.273 * * *$ \\
$\delta^{13} \mathrm{C}(\%)$ & 0.094 & $0.419 * * *$ & -0.022 & -0.017 \\
$\delta^{15} \mathrm{~N}(\%)$ & $0.217 * *$ & $0.783 * * *$ & 0.038 & $0.224 * * *$ \\
$\mathrm{C} / \mathrm{N}$ ratio & $0.233 * *$ & $0.846 * * *$ & 0.034 & $0.189 * * *$ \\
$\mathrm{TC}(\mathrm{mg} / \mathrm{g})$ & $0.786 * * *$ & $0.796 * * *$ & $0.324 * * *$ & $0.103 *$ \\
$\mathrm{TN}(\mathrm{mg} / \mathrm{g})$ & $0.900 * * *$ & $0.824 * * *$ & $0.406 * * *$ & $0.159 * * *$ \\
Population & - & $0.822 * * *$ & - & $0.121 * *$ \\
Temperature $\left({ }^{\circ} \mathrm{C}\right)$ & - & $0.288 * * *$ & - & $0.233 * * *$ \\
Precipitation $(\mathrm{mm})$ & - & -0.020 & - & 0.044 \\
Wind speed $(\mathrm{m} / \mathrm{s})$ & - & $0.384 * * *$ & - & -0.009 \\
All variables & $0.914 * * *$ & $0.912 * * *$ & $0.270 * * *$ & $0.136 * *$ \\
\hline
\end{tabular}
832 Significance codes for $P$-level: ‘***, $P<0.001$; “**’, $P<0.01$; ‘*’, $P<0.05$.

833 Note: An adjusted $R^{2}$ near 0 indicates that the environmental variable does not explain more of 834 the variation of the biotic assemblages change than random normal variable would do; Negative 835 adjusted $\mathrm{R}^{2}$ indicates that the explanatory variables perform similarly as random normal 836 variables would. 


\section{Figure captions}

2 Fig. 1 Site map (left) showing the location of Yilong Lake and lake morphometry (right).

Fig. 2 Time series of archived data showing the changes in annual mean temperature and precipitation (a), catchment population and wind speed (b), calculated water depth and lake area (c), nutrient variables total phosphorus and total nitrogen (d), Chl- $a$ and transparency (e) for Yilong Lake, respectively. Meterological data are from the National Climate Center (http://cmdp.ncc.cma.gov.cn/cn/index.htm); Population data were collected from the Shiping Yearbook (2005); TP, TN, Chl- $a$, transparency, water level and volume data were collected from previous studies (Chou and Xia, 1998; Ley et al., 1963; Li, 2009; Shi and Sun, 2005; Wei and Tang, 2014; Whitmore et al., 1997; Yang and Li, 2010).

11 Fig. 3 Depth profiles showing the ${ }^{210} \mathrm{~Pb}$ and ${ }^{137} \mathrm{Cs}$ radioactivities (a) and the CRS age model and sedimentation rate (b) for Yilong Lake.

Fig. 4 Sedimentary profile showing the proxies of grain sizes, nutrient concentrations and isotopes, as well as the diatom and pigment PCA site scores, for Yilong Lake.

Fig. 5 Stratigraphic profiles showing the temporal changes in pigment concentrations (ng/g OM)

16 for total algae and major components (a; Z:PD, the zeaxanthin:planktonic diatoxanthin ratio) and

17 the compositional change of common diatoms (>2\% relative abundance in at least one sample; b)

18 with the CONISS clusters at Yilong Lake. Colors denote the documented hydrological (green)

19 and extreme climate events (light blue), respectively, as detailed in Fig. 4.

Fig. 6 PCA biplots showing the first two axes for pigments (a) and diatom assemblages (b) in

21 Yilong Lake during1903-2013 AD.

Fig. 7 Biplots of redundancy analysis showing the selected significant drivers for pigment

23 concentrations (a) and diatom assemblages (b) during1903-2013 AD in Yilong Lake. 
24 Fig. 8 Results of variation partitioning and forward selection showing the minimum adequate

25 models for sediment (a) and lake-water Chl- $a$ (b), pigments and diatoms in Yilong Lake during

26 the time windows of 1903-2013 (c and d), and 1953-2013 (e and f), respectively. 
Fig. 1

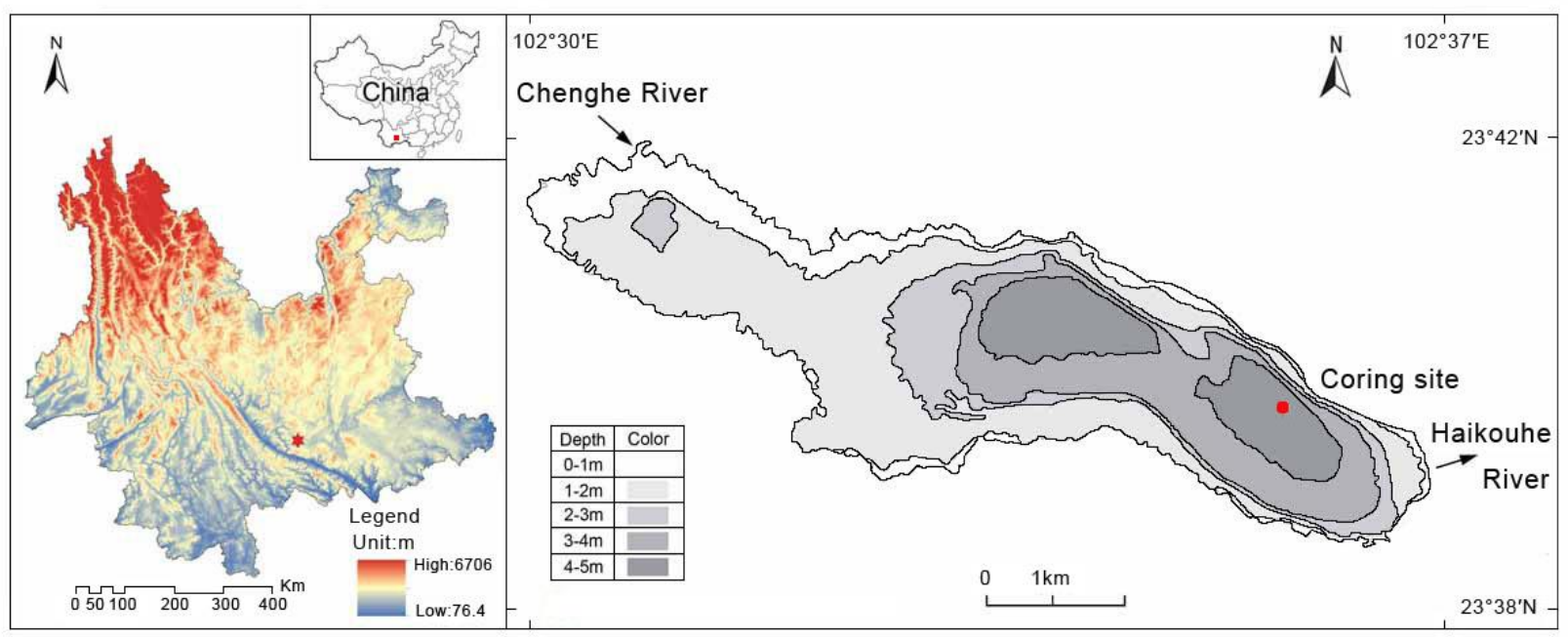

28 
Fig. 2
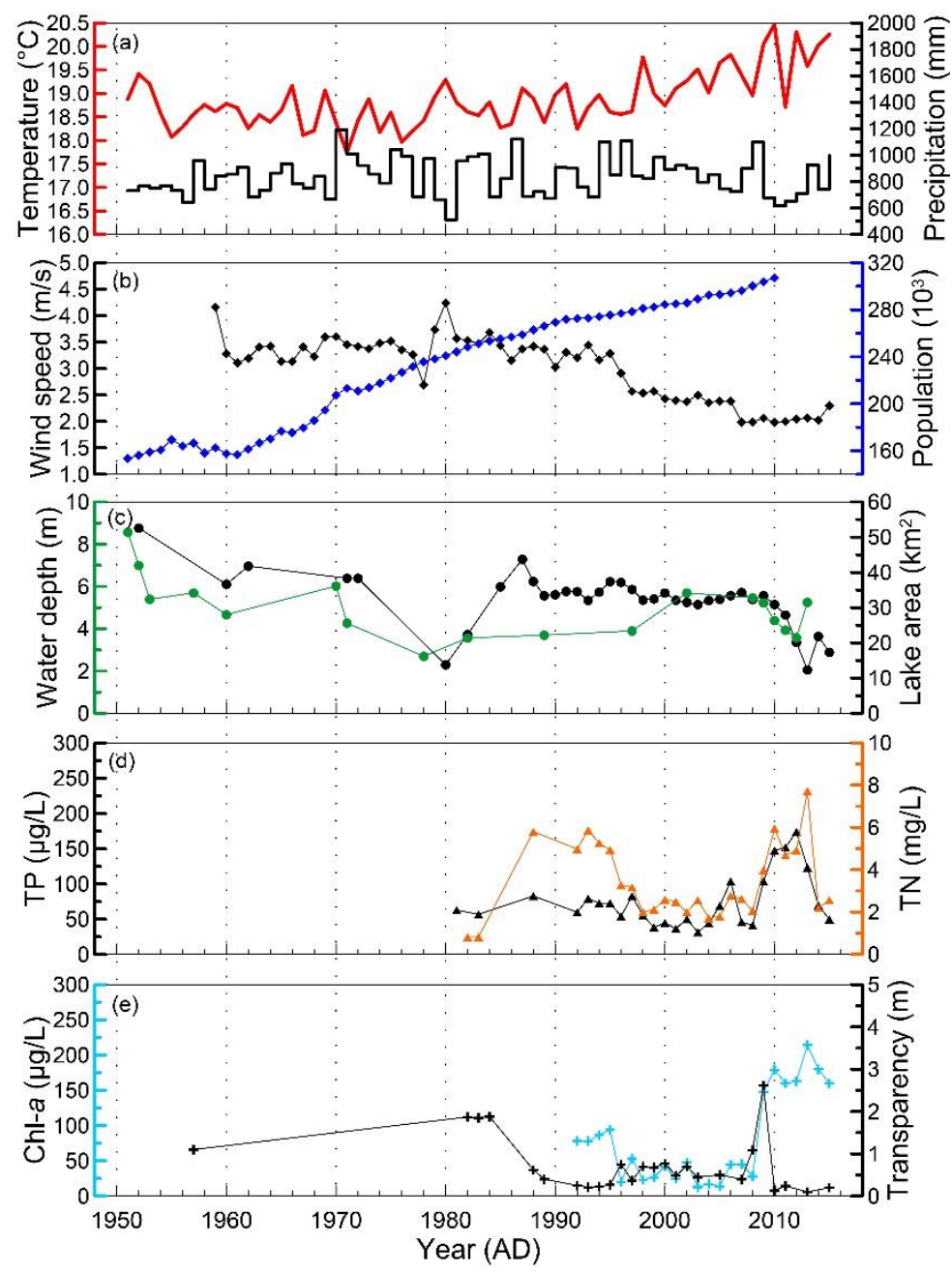
Fig. 3
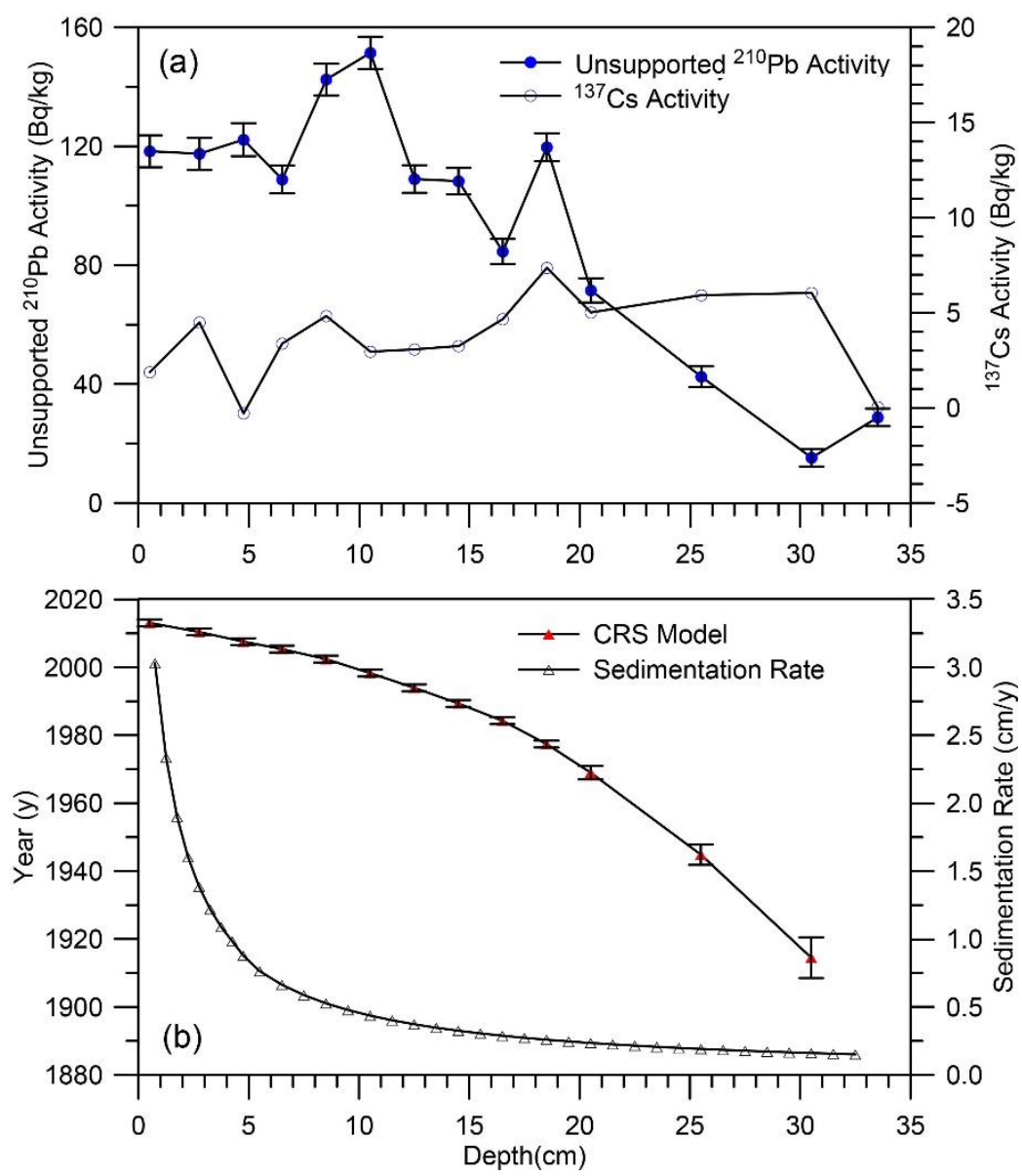
Fig. 4

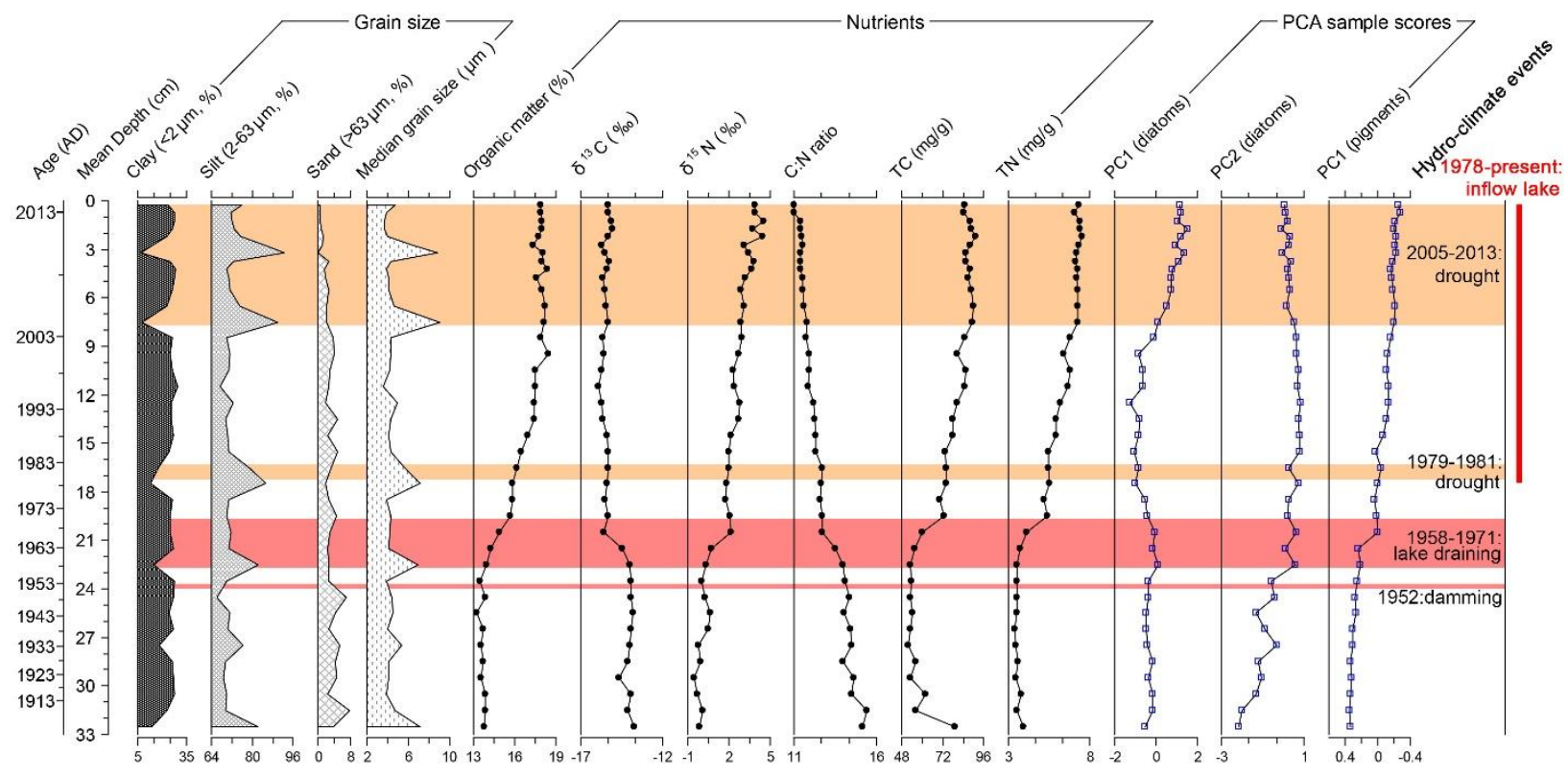


Fig. 5
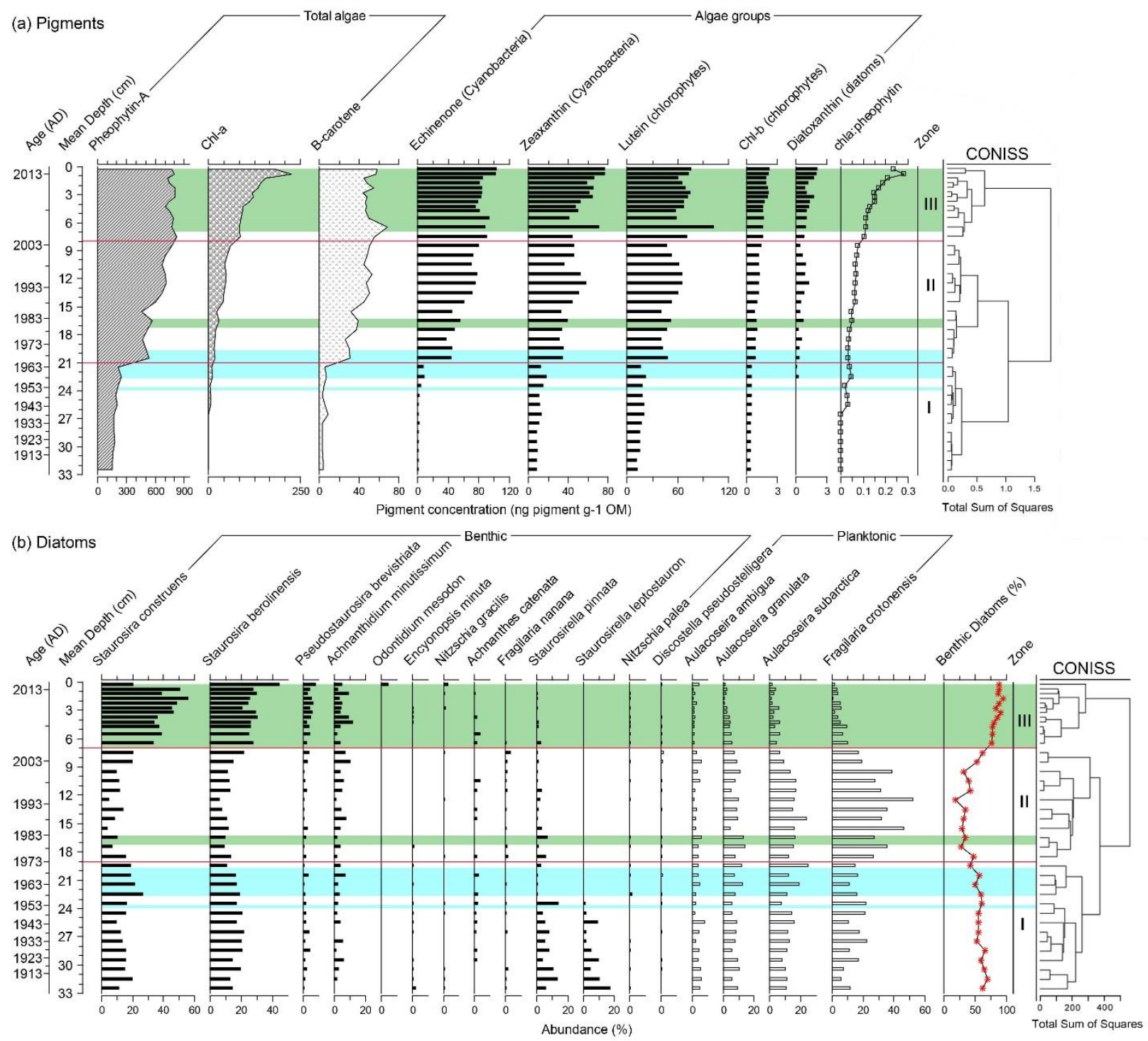
Fig. 6
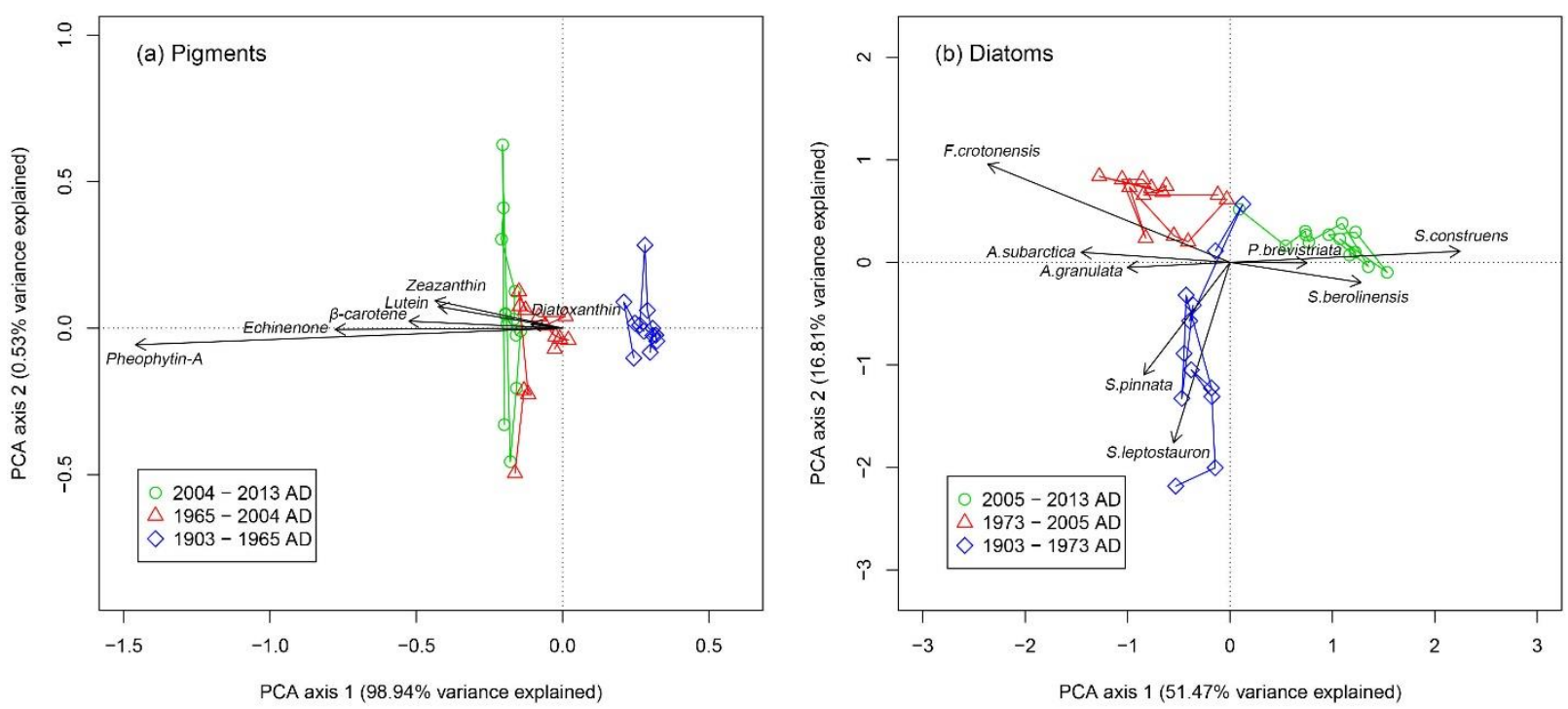

PCA axis 1 (98.94\% variance explained)

PCA axis 1 (51.47\% variance explained) 
Fig. 7
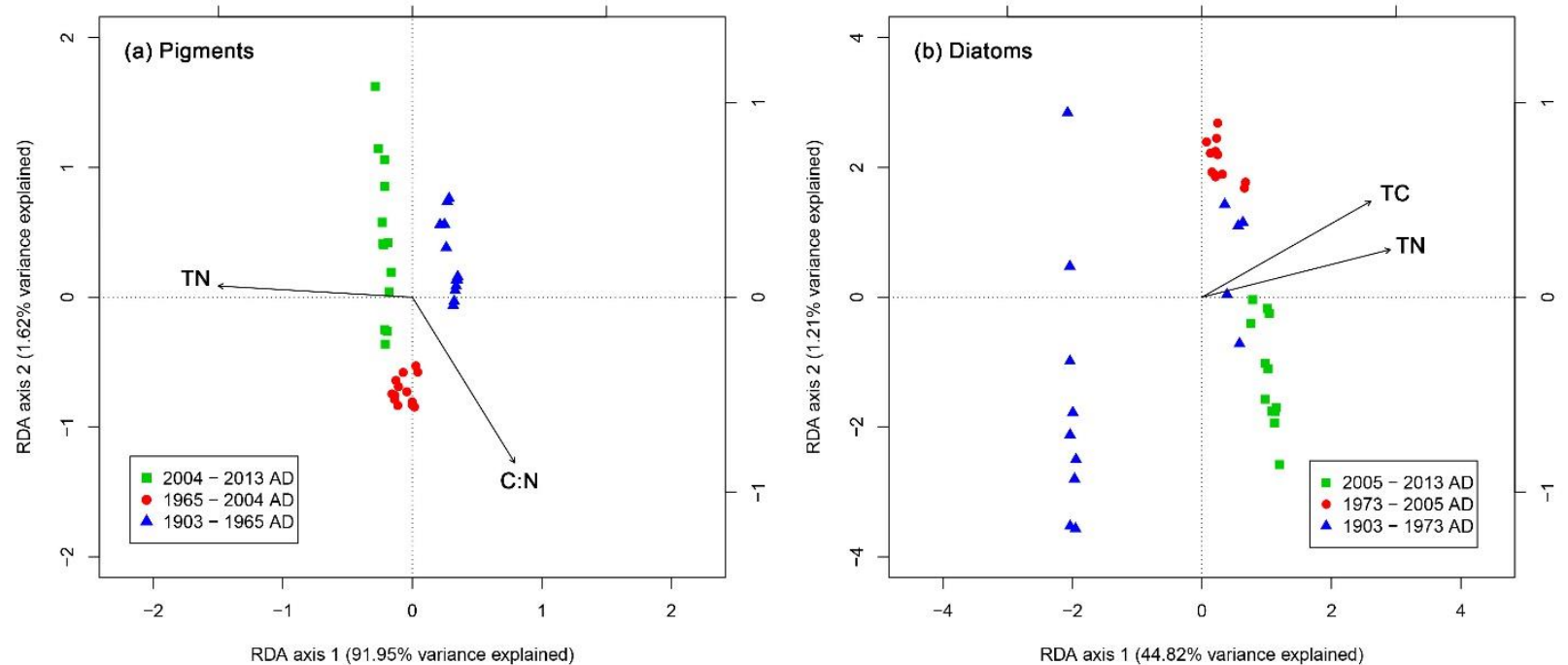
Fig. 8
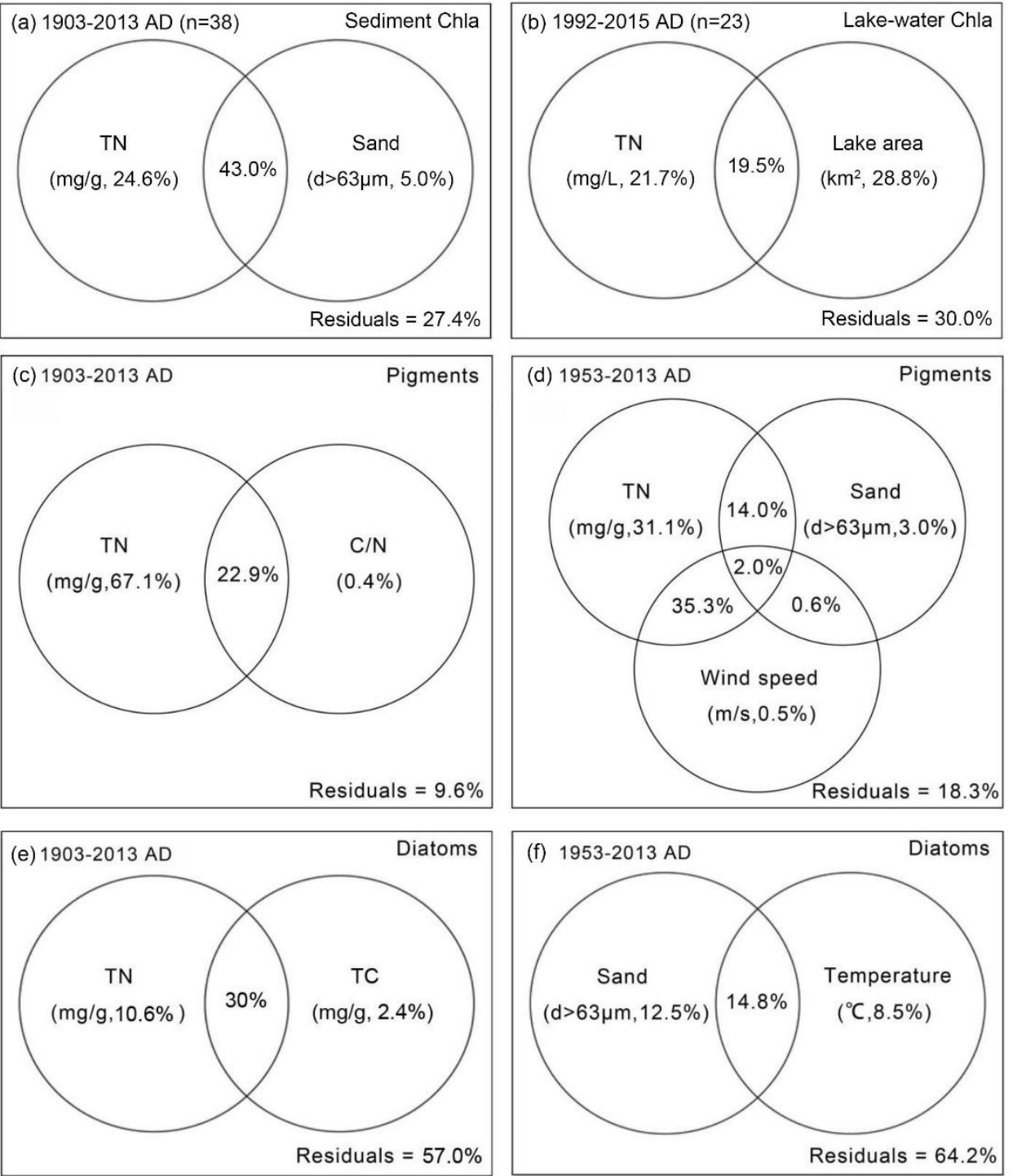
1

8 10

\section{Hydrological fluctuations modulate phototrophic responses to nutrient fertilization in a}

\section{large and shallow lake of Southwest China}

Kui Hu${ }^{1}$, Guangjie Chen ${ }^{1, *}$, Irene Gregory-Eaves ${ }^{2}$, Linpei Huang ${ }^{1}$, Xiaolin Chen ${ }^{1}$, Yuanyuan Liu,

Peter R. Leavitt ${ }^{3,4}$

6

${ }^{1}$ Yunnan Key Laboratory of Plateau Geographical Processes and Environment Change, School of

8 Tourism and Geography, Yunnan Normal University, Kunming 650500, China

${ }^{2}$ Department of Biology, McGill University, Montreal, Quebec H3A 1B1, Canada

${ }^{3}$ Institute of Environmental Change and Society, University of Regina, 3737 Wascana Parkway, Regina, SK S4S 0A2, Canada

${ }^{4}$ Institute for Global Food Security, Queen's University Belfast, Belfast, County Antrim, United Kingdom

*Email: guangjiechen@gmail.com, Tel: (+86) 13658805128 


\section{Abstract}

Lake nutrient budgets and hydrology are being altered by human activities and climate change,

assemblages of primary producers. Here, we present sediment records from a large shallow lake in Southwest China to separate the relative importance of nutrients and hydrological fluctuation in regulating the abundance and composition of primary producers during the $20^{\text {th }}$ century, with a focus on their differential effects on diatoms and cyanobacteria. Shifts in sedimentary particlesize distribution were consistent with the documented events of hydrological regulation during 1953-1971 and subsequent changes in water level associated with severe droughts. Nutrient enrichment since $\sim 1965$ resulted in a significant increase in the abundance of total phototrophs (pheophytin $a, \beta$-carotene) as inferred from pigment analyses, with stronger responses of cyanobacteria (echinenone, zeaxanthin) over siliceous algae (diatoxanthin). Fossil diatom assemblages revealed a pronounced replacement of benthic taxa by eutrophic and planktonic species (e.g., Fragilaria crotonensis) since $\sim 1973$, but we observed a significant increase of small benthic Fragilaria sensu lato taxa following $\sim 2005$, which generally corresponded with a moderate increase in fossil pigments. Although eutrophication was the paramount predictor of changes in phototrophs during the last century, variation in lake hydrology due to climate and water management also modulated phototroph abundances and, more recently, diatom assemblages. Specifically, our sediment evidence suggests that hydrological fluctuation has overridden fertilization by nutrients in structuring diatom composition, leading to a heterogeneous response of cyanobacteria and diatoms to external forcing of this shallow lake.

Keywords: Yilong Lake; pigments; diatoms; eutrophication; water regulation; extreme drought
删除的内容: tease out

带格式的: 字体:斜体 删除的内容: human hydrological 删除的内容: $\mathrm{s}$ 


\section{Introduction}

Lake phytoplankton and phytobenthos are known to be sensitive to environmental fluctuations such as climate change (Carvalho and Kirika, 2003) and nutrient fertilization (Jeppesen et al., 2005; Schindler, 2006). However, the relative importance of individual environmental controls may vary among basins, depending on algal identity and lake characteristics. For example, global warming can enhance phytoplankton production as temperature can directly affect algal photosynthesis and growth rate (Reynolds, 2006; Jöhnk et al., 2008). Prokaryotes, such as cyanobacteria, can be selectively promoted because their optimum growth rates occur at higher temperatures than do those of diatoms and other eukaryotic algae (Paerl and Huisman, 2008). Recent studies show that nutrient enrichment can also lead to a disproportional increase in the production of harmful algae when compared to other phytoplankton (Taranu et al., 2015), reflecting their competitive ability at high nutrient concentration (Tilman, 1987; Sterner and Elser, 2002). Furthermore, increased water-column stability due to atmospheric warming can enhance the production of harmful filamentous cyanobacteria in deep lakes (Huisman et al., 2005; Posch et al., 2012). However, nutrient fertilization can overwhelm climate control of algal production in shallow lakes (Taranu et al., 2012). Therefore, algal identity and lake typology should be considered in evaluating the strength of lake warming and eutrophication in driving primary producers (Vogt et al., 2018).

Shallow lakes are vulnerable to changes in climate and water influx due to their low volume and short water residence time when compared to deep lakes (Scheffer, 1998; Søndergaard et al., 2003). During the last few decades, anthropogenic regulation of water fluxes has been identified as a significant stressor for freshwaters in populous areas (Yang and $\mathrm{Lu}, 2014$ ), with a decline in lake water levels often stimulating algal production and favoring phytobenthos in shallow 
systems (Scheffer, 1998). At the same time, climate warming has increased the occurrence of extreme hydrologic events (e.g., droughts) at regional and global scales (Dai, 2011; IPCC, 2013), augmenting the decline of water level and ecological health (Lake, 2011). In comparison, nutrient fertilization usually enhances phytoplankton production at the expense of benthic taxa such as diatoms (Vadeboncoeur et al., 2003). In principle, changes in lake level and nutrient influx could drive algal abundance and community composition in different directions in shallow lakes that are subject to multiple stressors. Furthermore, there may exist strong interactions between nutrient dynamics and hydrologic fluctuation, as prolonged water retention time due to impoundment can lead to an increased level of nutrients (Maavara et al., 2015) and accelerate eutrophication in shallow lakes (Chen et al., 2013). To date, little is known of how such hydrologic fluctuations in shallow lakes may interact with eutrophication in regulating the abundance and composition of primary producers over time.

In many lakes, analysis of sedimentary records can provide a reliable temporal perspective on limnological responses to anthropogenic disturbances and climate change (Adrian et al., 2009; Battarbee, 2010; Smol, 2010). Fossil pigments and diatoms are two widely used paleolimnological indicators of algal abundance and community composition (Leavitt and Hodgson, 2001; Stoermer and Smol, 2001). For example, sediment pigments have recorded the independent effects of both nutrient fertilization and climate (Hall and Leavitt, 1999; Leavitt et al., 2006; Bunting et al., 2007), as have fossil diatom assemblages (Smol et al., 2005; Rühland et al., 2008). Diatoms from shallow lakes were found to be sensitive to lake-level changes through their response to habitat quantity and quality (Brugam et al., 1998), while shifts in the vertical zonation of algae with lake depth have been identified from fossil pigments (Cuddington and Leavitt, 1999; McGowan et al., 2005; Hambright et al., 2008). Therefore, 
sediment studies in shallow lakes can be applied to quantify the relative importance of multiple stressors in driving algal community structure and abundance over time.

We conducted sediment analyses to evaluate the long-term concordance between algal abundance and diatom assemblage composition in response to multiple stressors in Yilong Lake, southwest China. This large and shallow lake has undergone significant catchment development, hydrological regulation and extreme droughts since the 1950s (Cui and Zhai, 2006). Modern survey data also show a shift in phytoplankton density from predominately diatoms to mainly cyanobacteria during the last few decades (Zhao, 2013). Consequently, we predicted that both nutrient enrichment and variation in lake morphology could significantly enhance the production of phytoplankton over time, particularly that of cyanobacteria, while the intensification of water level changes may modulate the role of nutrients in altering the community structure of diatoms (i.e. an increase of phytobenthos). Combining sediment records with modern survey data, we first identified the temporal trajectories of phototrophic community composition, and then by applying multivariate statistics, we identified the relative importance of environmental factors which influenced phototrophs over different time intervals. Overall, this study provided evidence on dual effects of nutrients and hydrologic fluctuations on primary producer assemblages, with fertilization accelerating the growth of cyanobacteria-rich phytoplankton, while climate warming and hydrological management increased benthic diatoms over the last few decades.

\section{Material and methods}

\subsection{Study site}

Yilong Lake, located in southeast part of Yunnan Province, southwest China (Fig. 1), is a 
large $\left(\sim 34 \mathrm{~km}^{2}\right)$ shallow system with a maximum and average water depth of $\sim 3.7 \mathrm{~m}$ and $2.9 \mathrm{~m}$, respectively (Table 1). Yilong Lake is currently hyper-eutrophic with elevated concentrations of total phosphorus $(\mathrm{TP} ; \sim 120 \mu \mathrm{g} / \mathrm{L})$, total nitrogen $(\mathrm{TN} ; \sim 7.7 \mathrm{mg} / \mathrm{L})$ and Chlorophyll-a (Chl- $a$; annual precipitation is $928.3 \mathrm{~mm}$, a mean annual air temperature of $\sim 18{ }^{\circ} \mathrm{C}$ (Fig. 2) and an average insolation of 2,300 hours/year (Meteorology station of Mengzi County; http://cmdp.ncc.cma.gov.cn/cn/index.htm). Bedrock within the Yilong watershed is characterized by limestone and sandstone due to its Karst geology. The catchment vegetation is composed mainly of Yunnan pine (Pinus yunnanensis) and mixed deciduous species, with a forest cover of $\sim 34.2 \%$.

Currently, Yilong Lake is a semi-closed system, with a hydrological residence time of $\sim 2.4$ years (Li et al., 2015). However, Yilong Lake has been modified by both anthropogenic and climate forcing since the 1950s (Fig. 2). The main inflow of Yilong Lake is the Chenghe River, located at the northwest of the basin, which flows through the largest town within the catchment, Shiping (Fig.1). Lake area dynamics derived from monitoring data (Jin, 1995) and Landsat satellite imagery (Wu et al., 2016) document a consistent pattern of pronounced shrinking and reduced depth during 1952-1982 and 2009-2013 (Fig. 2). For example, dredging and damming of the outflowing Haikou River for electricity generation led to a decline in lake level by $\sim 2 \mathrm{~m}$ from 1952 (maximum depth $\sim 7.0 \mathrm{~m}$ ) to $1953(\sim 5.0 \mathrm{~m}$ ), and a further drop of $0.7 \mathrm{~m}$ in 1960 (Yang and $\mathrm{Li}, 2010)$. Lake area further reduced in 1971 with the construction of an underground tunnel for lake reclamation, which lead to a decline in maximum depth from $6.0 \mathrm{~m}$ in 1970 to $4.3 \mathrm{~m}$ in late low precipitation, the maximum water depth in Yilong Lake had declined further to $<1 \mathrm{~m}$ in 
spring of 1981, and then fluctuated between 3.6-5.5 m due to climatic and anthropogenic effects, including a period of extreme drought during 2008-2012 (Zhao, 2013).

With agricultural expansion and catchment development starting in $\sim 1955$, non-point source input of urban effluent (Zhao, 2013; Zhao et al., 2013). By 2007, annual TP and TN influx from farmland surface runoff accounted for $59 \%$ and $52 \%$ of total nutrient inputs, respectively (Wang and Wang, 2008). Furthermore, farming of fish within cages was initiated in 1985 and experienced an accelerating growth until 1997 (Shi and Sun, 2005), after which this practice was officially forbidden in Yilong Lake. During its period of operation, cage farming extensively harvested aquatic vegetation within the lake to feed herbivorous grass carp (Ctenopharyngodon idellus) (Chou and Xia, 1998), resulting in a rapid loss of macrophyte coverage from $95.0 \%$ in 1982 to $27.3 \%$ in 1992 (Table 2).

\subsection{Sample collection and sediment dating}

A 34-cm sediment core was collected from Yilong Lake in July 2013 from the deep basin $\left(23^{\circ} 39^{\prime} 53^{\prime \prime} \mathrm{N}, 102^{\circ} 36^{\prime} 15^{\prime \prime} \mathrm{E}\right)$ using a Renberg gravity corer (Fig. 1). The sediment core was sectioned immediately at $0.5-\mathrm{cm}$ intervals for the top $5 \mathrm{~cm}$ and at $1-\mathrm{cm}$ intervals for depths below $5 \mathrm{~cm}$. Samples were kept dark and frozen until subsampling for pigment analyses within $24 \mathrm{~h}$. The remaining sediments were freeze-dried and stored in the dark for subsequent analyses.

Sediment chronology was estimated based on ${ }^{210} \mathrm{~Pb}$ activities in sediment core samples. Around 3-5 g of freeze-dried sediments were used for measuring the radio-activities of ${ }^{210} \mathrm{~Pb}$ and

${ }^{137} \mathrm{Cs}$ in each sample using a Canberra well-detector gamma spectrometer (GCW 3023). The sediment chronology sequence was established with the constant rate of supply (CRS) model 
using the stratigraphic profile of unsupported ${ }^{210} \mathrm{~Pb}$ activities (Appleby, 2001).

\subsection{Sediment physical and geochemical analyses}

Grain-size distribution of sediment samples was determined using a Mastersizer 2000 laser disaggregated sediment from each sample was pre-treated with $10-20 \mathrm{ml}$ of $10 \% \mathrm{H}_{2} \mathrm{O}_{2}$ to remove organic matter and then heated in $10 \mathrm{ml}$ of $10 \%$ aqueous $\mathrm{HCl}$ to remove carbonates. Thereafter, $\sim 100 \mathrm{ml}$ of deionized water was added and the sample solution was kept for $24 \mathrm{~h}$ to remove acidic ions. The sample residue was dispersed with $10 \mathrm{ml}$ of $0.05 \mathrm{~mol} / \mathrm{L}\left(\mathrm{NaPO}_{3}\right)_{6}$ on an ultrasonic vibrator for 10 min prior instrumental analysis.

Organic matter $(\mathrm{OM})$ content was estimated for bulk sediments using the method of loss-onignition $\left(\%, \mathrm{LOI}_{550}\right)$ at $550{ }^{\circ} \mathrm{C}$ following the standard method (Heiri et al., 2001). Stable carbon (C) and nitrogen $(\mathrm{N})$ isotope analyses $\left(\delta^{13} \mathrm{C}\right.$ and $\left.\delta^{15} \mathrm{~N}\right)$ were conducted following the standard methods of Meyer (2001). Briefly, $10 \mathrm{mg}$ of homogenized, dried bulk sediment was combusted in a tin capsule at $960{ }^{\circ} \mathrm{C}$ in a FLASH 2000 elemental analyzer linked to a continuous isotope ratio flow mass spectrometer (MAT-253, Thermo Scientific, USA). C and N isotope ratios are expressed as per mil (\%) relative to Vienna Pee Dee Belemnite (VPDB) and atmospheric $\mathrm{N}_{2}$ (AIR), respectively. Relative contents of $\mathrm{C}$ and N (\% dry mass) and the mass ratio of carbon to nitrogen $(\mathrm{C}: \mathrm{N})$ were also measured. The analytical precision was $< \pm 0.1 \%$ for isotopic data and $< \pm 1 \%$ for elemental data, respectively.

\section{$\underline{2.4 \text { Pigment analyses }}$}

All pigments were measured following procedures described in Saulnier-Talbot et al. (2014) 
using high performance liquid chromatography (HPLC) at the Gregory-Eaves Lab of McGill University, Canada. Briefly, sediments were freeze-dried and pigments were extracted in acetone (at $-20{ }^{\circ} \mathrm{C}$ for $24 \mathrm{~h}$ ) before the extract solution was centrifuged and the supernatant filtered through a PTFE $(0.2-\mu \mathrm{m}$ pore) filter and placed in vials for pigment analysis. The analysis was conducted using a Waters HPLC system (model 600/626) equipped with a Waters Photodiode Array (model 2996) and a Waters 2475 Multi-wavelength fluorescence detector. The HPLC was calibrated previously using external standards from DHI (Denmark). Individual compounds were tentatively identified using a combination of chromatographic position (polarity) and spectral characteristics relative to authentic samples. Pigment concentrations were expressed as ng pigment/g organic matter, determined by mass loss on ignition at $550{ }^{\circ} \mathrm{C}\left(\mathrm{LOI}_{550}\right)$ for $1 \mathrm{~h}$. Cyanobacteria were represented by the carotenoid zeaxanthin and echinenone, while algal groups included compounds ubiquitous in phototrophs (chlorophyll- $a, \beta$-carotene, pheophytin- $a$ ), chlorophytes (lutein), crypotophytes (alloxanthin), and mainly diatoms (diatoxanthin). As Yilong Lake is a large system with documented hydrological fluctuations, we used the mass ratio of Chl$a$ :pheophytin to evaluate historical changes in pigment preservation and the importance of benthic phototrophs (Cuddington and Leavitt, 1999; Leavitt and Hodgson, 2001).

\section{$\underline{2.5 \text { Diatom analysis }}$}

Fossil diatoms were prepared for enumeration following the standard methods of Battarbee et al. (2001). Briefly, hydrochloric acid (10\%) was added for the removal of carbonates before processing, while $30 \%$ hydrogen peroxide was added at $\sim 80{ }^{\circ} \mathrm{C}$ to remove organic material. A portion of the digested slurry was dried on cover slips and mounted with Naphrax ${ }^{\circledR}$. Diatom identification and enumeration were performed under oil immersion at $1,000 \times$ magnification 
using a Leica DM 2500 microscope with phase contrast. A minimum of 400 valves was counted

for each sample. Diatom taxonomy mainly followed Krammer and Lange-Bertalot (1986-1991).

The community data were expressed as percent abundance of the total diatom sum in each

8214 9

sample. Diatom species were categorized into planktonic and benthic groups following their habitat preferences based on previous studies (e.g., Round et al., 2007).

\subsection{Numerical methods}

The major zones for the biostratigraphy were identified through the analyses of constrained incremental sum of squares (CONISS), while a broken-stick model was used to test for the significance of each break. We conducted ordination analyses to define the historical trajectories of pigment and diatom changes. Preliminary investigation with Detrended Correspondence Analysis (DCA) of pigment and diatom assemblages revealed short gradient lengths of 0.68 and 1.76 SD, respectively, indicating that pigments and diatom taxa responded in a linear fashion to environmental gradients (ter Braak and Prentice, 1988). Subsequently, Principal Components Analysis (PCA) was applied to extract the major direction of variation in both the diatom species compositions and fossil pigment assemblages. Pigment PCA used only the most chemicallystable pigments as suggested by Leavitt and Hodgson (2001) and Moorhouse et al. (2014). Redundancy Analysis (RDA) was performed subsequently to explore the relationship between biological data and nine environmental predictor variables (Hall and Leavitt, 1999; ter Braak and Šmilauer, 2002). Specifically, these environmental variables included grain size components, $\delta^{13} \mathrm{C}, \delta^{15} \mathrm{~N}, \mathrm{C}: \mathrm{N}$ ratio, total carbon and total nitrogen measured from bulk sediments (Table 3 ). Monte Carlo analysis with 999 permutations was used to test the significance of each predictor variable in partial RDA. Only variables with a P-value $<0.05$ were retained for the minimum 
adequate model (ter Braak and Šmilauer, 2002). In addition, environmental variables with a

variation inflation factor (VIF) of $>20$ were excluded due to their strong co-linearity with other variables.

\section{Results}

\subsection{Archived data}

Meteorological data generally show a warming trajectory with marked variation in precipitation during the last six decades. The annual mean temperature shows a warming trend, increasing from an average $( \pm \mathrm{SD})$ of $18.5 \pm 0.3^{\circ} \mathrm{C}$ during $1951-1990$ to a mean of $19.2 \pm 0.6^{\circ} \mathrm{C}$ for the last two decades (Fig. 2a). The annual precipitation displays no clear trend since 1951, but shows reduced values $(<600 \mathrm{~mm})$ during the intervals of 1961-1962, 1979-1980, 1987-1989,

\begin{tabular}{l|} 
删除的内容: ed \\
删除的内容: $( \pm \mathrm{SD})$ \\
删除的内容: ed \\
删除的内容: $\mathrm{n}$ \\
删除的内容: increasing \\
删除的内容: with a mean of $19.2 \pm 0.6^{\circ} \mathrm{C}$ for the last two \\
decades, but was is relatively stable \\
删除的内容: with an average of $18.5 \pm 0.3^{\circ} \mathrm{C}$ \\
删除的内容: ed \\
删除的内容: ed
\end{tabular}


2004-2005 and 2010-2012. Annual wind speed (Fig. 2b) is relatively stable during 1951-1995

$(3.4 \pm 0.3 \mathrm{~m} / \mathrm{s})$, but declines to $2.3 \pm 0.3 \mathrm{~m} / \mathrm{s}$ by 2010 . Lake level and surface area both decrease over the last six decades, with abrupt drops in the mid-1950s, late-1970s and during 2009-2013
(Fig. 2c). Meanwhile, the total catchment population doubles during the last six decades (Fig. 2b).

Variables related to lake primary production and water quality indicate a substantial increase in primary producer abundance over the historical record (Fig. 2). The lake-water concentrations of TN, TP and Chl- $a$ have experienced a rapid increase concomitant with a decline in transparency from $>2 \mathrm{~m}$ to $<1 \mathrm{~m}$ during 1985-1997 (Fig. 2e) and a rapid loss of submerged aquatic vegetation (Table 2). For example, the mean concentration of measured total phosphorus (TP) and total nitrogen (TN) show ${ }_{\vee}$ an undulating pattern since late 1980 s, but a clear tendency to nutrient enrichment during $2009-2012$ (Fig. 2d). From the mid-1980s to the mid-1990s, TP and TN levels are elevated with a mean $( \pm \mathrm{SD})$ of $75.2 \pm 21.2 \mu \mathrm{g} / \mathrm{L}$ and $5.0 \pm 0.6 \mathrm{mg} / \mathrm{L}$, respectively. Nutrient content is relatively stable during the $2000 \mathrm{~s}(\mathrm{TP}=54.0 \mu \mathrm{g} / \mathrm{L}, \mathrm{TN}=1.8 \mathrm{mg} / \mathrm{L})$, before increasing after $\sim 2009$ (Fig. 2d). In general TP and TN increase at similar rates $(r=0.68, p<$ $0.001, \mathrm{n}=21$ ), with a $\mathrm{N}: \mathrm{P}$ mass ratio consistently above 20 (or molar ratio of 44) since 1988 (Table 2).

Monitoring data show that Chl-a values are relatively high in the mid-1990s (ca. $100 \mu \mathrm{g} / \mathrm{L}$ ), decline to minima $(<50 \mu \mathrm{g} / \mathrm{L})$ for 15 years, then increase to historical maxima $(>150 \mu \mathrm{g} / \mathrm{L})$ after 2010 (Fig. 2e). At the sample time, measured phytoplankton density increase gradually from $8.41 \times 10^{6}$ cells $/ \mathrm{L}$ in 1957 to $193.21 \times 10^{6}$ cells $/ \mathrm{L}$ in 1992 , and thereafter from $<100 \times 10^{6}$ cells $/ \mathrm{L}$ during 1993-2008 to $>200 \times 10^{6}$ cells/L after 2008 (Table 2). During this period, phytoplankton community composition gradually shifts from predominantly Bacillariophyta in 1957 to Chlorophyta in 1988 and 1993, and, more recently, to Cyanobacteria (Table 2). Consistent with
删除的内容: wa

\section{删除的内容: $d$}

删除的内容: d

删除的内容: ed

删除的内容: $d$

删除的内容: $\mathrm{s}$

删除的内容: were

删除的内容: was

删除的内容: d

\begin{tabular}{l|} 
删除的内容: suggests \\
删除的内容: were \\
删除的内容: $d$ \\
删除的内容: $d$ \\
删除的内容: $d$ \\
\hline
\end{tabular}



since 2010 (Fig. 2e).

\subsection{Sediment chronology}

The unsupported ${ }^{210} \mathrm{~Pb}$ radioactivity profile declined with increasing core depth between 10 and $\sim 30 \mathrm{~cm}$ (Fig. 3a), suggesting that the ${ }^{210} \mathrm{~Pb}$-based CRS model was applicable in constructing the chronological profile. Sediment samples above the $\sim 7 \mathrm{~cm}$ depth showed a uniform ${ }^{210} \mathrm{~Pb}$ activity, possibly reflecting sediment mixing or variation in sediment focusing due to changes in basin morphology (Fig. 2c). In lakes where mixing has occurred, the ${ }^{210} \mathrm{~Pb}$ dates covering 10 year accumulation, as is the case for this sediment core (Fig. 3b), often provide a maximum error of less than 2 years (Appleby, 2001). Increased autochthonous production which would dilute the atmospheric ${ }^{210} \mathrm{~Pb}$ fallout may also cause a decrease in its activity as observed in surface sediments above $\sim 7 \mathrm{~cm}$ (Fig. 3a). The depth profile of ${ }^{137}$ Cs showed no obvious peak (Fig. 3a), reflecting a possible combination of sediment mixing and post-deposition mobility (e.g., Wieland et al., 1993; Sommerfield and Nittrouer, 1999). Overall, radio-isotope profiles and CRS calculations suggest a recent acceleration in the rate of sediment accumulation (Fig. 3b).

\subsection{History of lake environmental change}

Grain size data showed modest changes over the length of the core (Fig. 4), with a decline in sand particles and the occurrence of abrupt fluctuations in median grain size during the last century. For example, the median size varied around a mean ( $\pm 1 \mathrm{SD}$ ) of $4.8 \pm 1.4 \mu \mathrm{m}$, with the clay $(<2 \mu \mathrm{m})$ and sand $(>63 \mu \mathrm{m})$ components varying in the range of $7.2-30.0 \%($ mean $=25.8 \%)$ 
and $0.03-7.7 \%$ (mean $=1.7 \%)$, respectively. Both the silt composition and median grain size spiked around the depths of 23.5, 17.5, 7.5 and $3.25 \mathrm{~cm}$ (Fig. 4).

Stable sedimentary TN content in the early $20^{\text {th }}$ century $(3.6 \pm 0.2 \mathrm{mg} / \mathrm{g})$ gave way to an increase since $\sim 1970$, with a recent mean of $6.7 \pm 0.8 \mathrm{mg} / \mathrm{g}$ (Fig. 4). The concentrations of both total carbon (TC) and organic matter $\left(\mathrm{LOI}_{550}\right)$ displayed similar trajectories suggesting that lake production increased after the late-1960s. The mass ratio of $\mathrm{C} / \mathrm{N}$ in bulk sediments declined from historical values of $\sim 16$ to modern ratios of $\sim 11$, consistent with an increasing input of organic matter derived from algae.

The $\delta^{15} \mathrm{~N}$ signal of bulk sediments remained stable around the near-atmospheric value $(\sim 0 \%)$ until the mid-1960s, at which time it increased dramatically up to a maximum value of $\sim 4.5 \%$ in surface sediments. Correspondingly, the bulk sediment $\delta^{13} \mathrm{C}$ signal declined from around $-14 \%$ to nearly $-16 \%$ over the $20^{\text {th }}$ century, with a marked decline after $\sim 1960$. These relatively enriched values are characteristic of lakes with high carbonate content in sediments (Jarvis et al., 2006), and were correlated inversely with the total algal abundance as measured by the total phototroph biomarker, $\beta$-carotene $(\mathrm{r}=-0.92, \mathrm{P}<0.001)$.

\subsection{Pigment variations}

Analysis of sedimentary pigments suggested a progressive increase in autotrophic production during the 20th century with a particularly marked upturn starting in the mid-1960s for most of the major taxonomic groups (Fig. 5a). The concentrations of many pigment biomarkers were low and stable prior to the mid $20^{\text {th }}$ century (zone I), including chemicallystable (pheophythin- $a, \beta$-carotene) and labile (Chl- $a$ ) indices of total phototrophic abundance, as well as pigments from bloom-forming cyanobacteria (zeaxanthin, echinenone). During 1965- 


\subsection{Diatom compositional changes}

A total of 62 diatom taxa were identified in sediment samples, including 23 taxa with a maximum abundance of $\geqslant 1 \%, 16$ of which occurred with a relative abundance of $\geqslant 2 \%$ in at least one sample. Diatom assemblages were composed mainly of benthic species with strong variations amongst taxa over the $20^{\text {th }}$ century (Fig. 5b). For example, Staurosira construens (a 
exhibited wide variation in relative abundance. Benthic diatoms were generally predominant ( $>$

$50 \%$ relative abundance) across the core except in the depths of 17.5-9.5 $\mathrm{cm}(\sim 1978-2000)$, at

which time planktonic and tychoplanktonic diatoms became more important within the assemblage $(\sim 50-80 \%$ of total frustules). Planktonic diatoms mainly included Fragilaria crotonensis (1.2-52.4\%), while tychoplanktonic taxa were composed of Aulacoseira subarctica (1.6-25.1\%), A. granulata (0.7-14.7\%), and A. ambigua (1.0-8.2\%).

Similar to the pigment changes, diatom assemblages were characterized by two significant shifts (Fig. 5b). During the period of $\sim 1903-1973$ (zone I), the community was composed of both benthic taxa, such as $S$. berolinensis (mean $=17.7 \%)$ and $S$. construens $(16.8 \%)$, and several planktonic taxa such as F. crotonensis (15.1\%) and A. subarctica (13.2\%). After 1973 (zone II), there was a significant community shift towards more eutrophic taxa and an associated decrease in small benthic Fragilaria sensu lato taxa, coupled with an increase in F. crotonensis to over 30\% and the disappearance of S. leptostauron. After 2005 (zone III), the community was characterized by the replacement of planktonic taxa such as F. crotonensis and Aulacoseira spp. $(<10 \%)$ by small benthic taxa such as $S$. construens and $S$. berolinensis (mean $=40.8 \%$ and $28.3 \%$, respectively).

Principal components analysis (PCA) of diatom data showed that the first two PCA axes were statistically significant based on the broken-stick model, accounting for $51.5 \%$ and $16.8 \%$ of the total variance, respectively (Fig. 6b). Planktonic species (such as F. crotonensis, A. subarctica, A. granulata) were strongly associated with the left side of axis 1 , with several benthic species such as $S$. construens and $S$. berolinensis sitting at the opposite end of this axis. PC axis 1 further showed a significant correlation with the proportion of benthic diatoms $(\mathrm{r}=$ 
$0.953, \mathrm{P}<0.001)$, as well as the sand component $(\mathrm{r}=0.571, \mathrm{P}<0.001)$ and $\mathrm{TN}(\mathrm{r}=0.548, \mathrm{P}<$ 0.001). In contrast, benthic taxa such as $S$. pinnata and $S$. leptostauron were more abundant during the period of 1903-1973 (zone I) and were strongly associated with PCA axis 2, which

itself displayed a significant correlation with $\mathrm{TN}(\mathrm{r}=0.606, \mathrm{P}<0.001)$. Only PCA axis 1 showed

during the $\sim 1953-2013$ interval.

\section{$\underline{\text { 3.6 Identifying limnological drivers for algal changes }}$}

The Redundancy Analysis (RDA) suggested that nutrient and hydrological parameters played independent roles in shaping the temporal changes in primary producer assemblages of Yilong Lake (Fig. 7). The measured physio-chemical variables collectively accounted for the majority of the changes in pigments (i.e. $>90 \%$ ), but less than half of the historical variation in diatom assemblages (Table 3). Specifically, nutrients (i.e. TN) were found to be the most significant forces in driving the changes of both pigments and diatoms since $\sim 1903$. The nutrient-associated RDA axis 1 accounted for $92.0 \%$ of the total variance for pigment data but smaller amount for diatom data (42.3\%; Fig. 7). Over a shorter time window of $\sim 1953-2013$ (Table 3), nutrient variables remained as the predominant factor in driving pigment changes $(>90 \%)$ but structured diatom assemblages to a much lesser degree $(<15 \%)$. In contrast, the grain-size proxies played an insignificant role in driving both indicators over the last century; however, the sand content was identified as a significant factor over the last six decades and accounted for $\geqslant 20 \%$ of the total variance for both pigments and diatoms. Temperature also displayed a significant impact on both algal indicators since $\sim 1953$ (28.8\% and $23.3 \%$, respectively), but wind speed was found to be a major driver only for pigments (38.4\%; Table 3). 
The variance partitioning results further showed that lake-water $\mathrm{TN}$ concentration, but not TP, was a significant diver, accounting for $21.7 \%$ of the change in water-column Chl- $a$ for the monitoring period of 1992-2015 (Fig. 8b). Furthermore, hydrologic fluctuation inferred from changes in lake area independently explained $28.8 \%$ of the total variance in lake-water Chl- $a$, with a high proportion shared with nutrients (19.5\%) over the monitoring period. Likewise, sediment TN alone explained $24.6 \%$ of the total variance in sedimentary Chl- $a$, while the variation of sediment sand content alone accounted for $5.0 \%$ of the total variance in Chl- $a$ with a strong interaction with nutrients $(43.0 \%)$ during the last century (Fig. $8 \mathrm{a})$.

Over the whole core, sedimentary TN collectively accounted for a large proportion of the total variance for both algal pigments and diatom assemblages (i.e. $90.0 \%$ and $40.6 \%$, respectively; Fig. 8c, e). However, the nutrient effect was found to be insignificant for diatom assemblages during $\sim 1953-2013$ (Fig. 8f), whereas it accounted for the majority of the total variance in phototrophic abundance over the same time window (82.4\%; Fig. 8d). In comparison, the relative importance of hydrological fluctuation (as inferred from sand content) for diatom assemblages increased from $4.7 \%$ (Table 3 ) over the core to $27.3 \%$ during $\sim 1953-2013$ (Fig. 8f), the period when temperature was also found to be a significant driver $(8.5 \%)$ and interacted moderately with hydrological fluctuation (14.8\%; Fig. 8f). From $\sim 1953$, both wind speed and hydrological fluctuation showed a strong influence on algal production, but mostly through its interaction with nutrients such as TN (i.e. $35.3 \%$ and $14.0 \%$, respectively; Fig. 8 d).

\section{Discussion}

Our multi-proxy sedimentary records revealed a clear trajectory of phototrophic changes in response to a combination of nutrient enrichment and hydrologic fluctuation in Yilong Lake 
during the last century. The sedimentary record of fossil pigments showed a dramatic increase concomitant with nutrient enrichment, while more recent changes in production appear to correspond to declining water level and wind speed. Meanwhile, the sediment records of grain size (e.g. sand content and median size) documented the role of hydrological regulation and extreme droughts on lake levels, which affected algal production and diatom assemblages over time. Diatom community composition showed two significant shifts during the past century; with a gradual replacement of oligotrophic taxa by eutrophic species since $\sim 1973$, and a distinct increase in small benthic Fragilaria sensu lato taxa in after 2005 . In general, diatom community composition was structured mainly by nutrient enrichment over the $20^{\text {th }}$ century, although effects of hydrologic fluctuations appear to have been more pronounced in the past two decades.

\section{$\underline{4.1 \text { Lake eutrophication and phototrophic responses }}$}

Our sedimentary records of lake eutrophication were highly consistent with patterns recorded from monitoring data for Yilong Lake. As the human population in the catchment began to increase in the 1960 s, sediment TN values steadily increased, with a concomitant decrease in bulk sediment $\mathrm{C} / \mathrm{N}$ ratios and $\delta^{13} \mathrm{C}$ values after the 1960 s (Fig. 4), patterns that are consistent with increased input of nutrients and autochthonous C sources (Meyers and Ishiwatari, 1993). For example, an annual input of 341 and 40 tons of TN and TP was estimated for the early 1990s (Chou and Xia, 1998). The archival data showed that the content of lake-water nutrients and Chl$a$ generally increased concurrent with a decline in lake-water transparency during 1985-1997 and 2009-2013 (Fig. 2). The decline of the bulk sediment carbon isotopic signal, coupled with an increase in cyanobacteria, suggested a shift of carbon source and transfer towards a planktonic 
pathway typical of eutrophic subtropical (Xu et al., 2014) and temperate lakes (McGowan et al., 2005). The rise in $\delta^{15} \mathrm{~N}$ is also consistent with the release of isotopically-enriched pollutants arising from urban (Leavitt et al., 2006) and agricultural sources (Bunting et al., 2007), while the depletion of $\delta^{15} \mathrm{~N}$ prior to the mid-1960s may be linked with deposition of atmospheric nitrogen (Kang et al., 2019) and/or a paramount importance in fixed nitrogen within the lake (Hayes et al., 2019). dramatically from $\sim 1965$ in a pattern similar to that observed in other lakes impacted by agriculture (Bunting et al., 2007; Moorhouse et al., 2014) and urbanization (Leavitt et al., 2006). Similar long-term increases in primary producer abundance as a result of intensified catchment development have been recorded in other lakes within this study region (Wu et al., 2002; Shi and Sun, 2005), as well as those from eastern China (Xu et al., 2014; Deng et al., 2016). Furthermore, these changes are generally consistent with a 100 -fold increase in the cell density of monitored lake-water phytoplankton during the last few decades (Table 2). Similarly, monitoring programs within Yilong Lake reveal that the dominant phytoplankton by cell density gradually shifted from Bacillariophyta in 1957 to positively-buoyant (and more easily sampled) Cyanobacteria since 1997. The moderate concentration for cyanobacterial pigments, such as zeaxanthin, prior to $\sim 1965$ was consistent with the presence of cyanobacterial blooms of Microcystis aeruginosa in 1957 (Ley et al., 1963).

Nutrient input also led to significant shifts in the diatom community, although effects of fertilization appear to have declined in the last decade. For example, the period of $\sim 1973-1998$ was characterized by a rapid enrichment in $\mathrm{TN}$ and the predominance of $F$. crotonensis, a planktonic species often found in nutrient-enriched lakes (Bennion et al., 2009; Hu et al., 2012). 
This taxon declined during the period of 1998-2008, when lake-water nutrients and algal production were lower (Fig. 2), and there existed a moderate drop in sediment pigment concentrations (e.g. zeaxanthin and lutein). Since $\sim 1998$, the abundance of small benthic 7

Fragilaria sensu lato taxa increased significantly at the expense of planktonic diatoms in Yilong

Lake, suggesting a decreasing role of nutrients in driving diatom community reorganization over the last decade. Finally, from the late 2000s, analyses of monitoring and sediment data suggest that cyanobacterial abundance has increased relative to that of diatoms. Similarly, increasing dominance of cyanobacteria has been well recorded in regional studies of temperate lakes under nutrient-enriched conditions (Taranu et al., 2015).

\section{$\underline{4.2 \text { Hydrological and climatic impacts on algae }}$}

Analyses of sediment grain size distribution, together with archival environmental data, provide evidence for that hydrologic fluctuations served as a significant driver of phototrophic community change. Specifically, the hydrologic fluctuation inferred from changes in sediment sand content explained a large proportion of the variance in sediment Chl- $a$ pigments, while variation in lake area (another hydrological proxy) was a strong predictor of changes in lakewater Chl- $a$ concentration (Fig. 8). A moderate decrease of sediment sand content starting from the 1950s corresponds to the documented history of hydrological regulation and decreased water levels (Cui and Zhai, 2006). Lake regulation often decreases the natural variation of water level and lake turbulence (Menking, 1997; Digerfeldt et al., 2000), resulting in a gradual decrease in the sand component over time (Wang et al., 2019). Similarly, the spikes in median grain size were synchronous with several major events of extreme drought over the last six decades (Figs. 2a and 4). Lake regulation can often amplify the nutrient effect and promote algae production by 
concentrating nutrients (Serruya and Pollingher, 1977; Peršić et al., 2007), enhancing nutrient retention (Maavara et al., 2015) and reducing water turnover (Posch et al., 2012). Accordingly, our results showed a pronounced increase in the content of sediment nutrient and pigment concentrations starting from $\sim 1953$ (Fig. 4), as well as a significant interaction between hydrologic fluctuation and nutrients (Fig. 8) at this time. These patterns are consistent with earlier studies of other hydrologically-managed and drought-sensitive shallow lakes based on monitoring data (Yang and Lu, 2014) and sediment records (Chen et al., 2011).

Previous surveys show that phototrophic response to nutrient concentrations within lakes can be modulated by both warming (Vogt et al. 2018) and extreme climate (Anderson, 2000; Berthon et al., 2014). Recent warming during the last two decades has been identified as an important factor regulating diatom compositional shift in this study region (Chen et al., 2014a), as well as in many parts of the world (Winder and Hunter, 2008; Finkel et al., 2009; Rühland et al., 2015). The stability of water column can be further enhanced by a falling wind speed (i.e. $<3 \mathrm{~m} / \mathrm{s}$ ) during the last two decades, which often favors the bloom of buoyant cyanobacteria such as Microcystis in eutrophic shallow lakes (Zhang et al., 2012). The most recent drought, occurring during 2009-2012, reduced lake levels by $\sim 2.3 \mathrm{~m}$ with a loss of $\sim 0.67$ billion $\mathrm{m}^{3}$ of water (Wang et al., 2014). Meanwhile, the shift from planktonic diatoms to small benthic Fragilaria sensu lato taxa indicated the expansion of littoral taxa. This can result from warming-associated hydrodynamic change (i.e. increased evaporation; Byllaardt and Cyr, 2011), and the loss of lake volume which was caused by severe droughts and possibly amplified by elevated water use due to an increased population size (Fig. 2 and Table 2).

In 2010, the dominant Cyanobacteria (Microcystis) was replaced by Cylindrospermopsis raciborskii (Table 2), a species that can tolerate varying N:P ratios (Barica et al., 1980) as well as 
extreme droughts (Marc et al., 2000). Similarly, there was a clear loss of Aulacoseira spp. during the last decade, a taxon which had been consistently subdominant in diatom assemblages over much of the core (Fig. 5b). Aulacoseira taxa have a high siliceous content and are known to proliferate in frequently-mixed waters that favor resuspension of these heavy taxa (Reynolds,

8548 10549 11 $12^{550}$

1987; Chen et al., 2011). This trend was synchronous with the recent decrease of wind speed, that was widely observed across China and linked with the weakening east Asian monsoon (Xu et al., 2006). Therefore, changes in lake level and thermal stability may favor specific algae in the context of regional warming (Wagner and Adrian, 2009; Romo et al., 2013).

\section{$\underline{4.3 \text { Heterogeneity in algal responses to multiple stressors }}$}

Despite pigment and diatom data exhibiting generally coherent shifts during the past century (Fig. 4a, b), there exist key differences in the importance of nutrient supply to the apparent production of individual photosynthetic groups. For example, the strong relationship between sediment $\mathrm{TN}$ and cyanobacteria pigments agrees with the demonstrated ability of lakewater TN to predict cyanobacteria abundance in temperate regions (Beaulieu et al., 2014) and the positive response of primary producers to $\mathrm{N}$ influx (Leavitt et al., 2006; Bunting et al. 2007). N supply to Yilong Lake may have limited algal growth early in the $20^{\text {th }}$ century, when sedimentary $\delta^{15} \mathrm{~N}$ was low and characteristic of fixed $\mathrm{N}_{2}$ from diazotrophic cyanobacteria, and disproportionately high $\mathrm{P}$ influx occurred with agricultural development in 1960s (Shiping Yearbook, 2005), leading to a low N:P mass ratio of 12.9-14.4 (Fig. 2). Thereafter, this shallow system was characterized by a consistently high N:P mass ratio (i.e. $>40$ ) for the past two decades (Table 2), suggesting that the content of $\mathrm{P}$, coupled with increasing $\mathrm{N}$ influx, may have impacted algal production through changing N:P ratio (Li et al., 2015). Later on, a rapid decrease 
of $\mathrm{N}: \mathrm{P}$ mass ratio from $>80$ to $<50$ corresponded to a shift of dominant Cyanobacteria from heterocystous diazotroph Aphanizomenon flosaquae in 1992 to non-nitrogen fixing Microcystis aeruginosa in 1997 and 2008, respectively (Table 2). This pattern suggests that non-nitrogen

\section{删除的内容: the}

删除的内容: impact

Our comparative study highlights the increasing effects of hydrologic fluctuations and regional climate variability on variation in phototrophs over the last few decades. Noticeably, an increase in the lake-water Chl- $a$ concentration and its sediment pigment is strongly linked with hydrologic fluctuations over time (Fig. 8a, b). Even though the increased ratio of chlorophyll$a /$ pheophytin- $a$ (Fig. 5a) suggested an incomplete pigment degradation and preservation in sediments during 2004-2013, the major pigment components generally display an increasing trend of Chl- $a$ and cyanobacteria concentrations that are comparable with lake-water surveys (Fig. 2e and Table 2). Meanwhile, the benthic diatom percentage rose sharply as water column depth declined during the last two decades, despite the concurrent decline in macrophyte coverage (Table 2). The rapid rise in the cyanobacteria (zeaxanthin) pigments also suggests that there was an increase in the growth of cyanobacteria at the expense of other algae as observed in other shallow lakes (McGowan et al., 2005). Previous studies show that hydrologic fluctuation could serve as a key driver of algae in nutrient-enriched shallow lakes through increasing benthic production (Vadeboncoeur et al., 2003), or even overiding nutrients in structuring diatom composition (Liu et al., 2017). More recently, water level drops may have exposed more benthic habitats (e.g. mud and rocks) favoring, small Fragilaria sensu lato taxa as is found in neighboring shallow lakes (Liu et al., 2017; Kang et al., 2019). The diatom compositional change is also broadly consistent with the finding that lake depth could play a significant role in
删除的内容: of 
affecting biotic responses to climate change in polymictic lakes (Chen et al., 2014b). Therefore, the role of nutrients was relatively truncated in driving diatom composition with hydrologic modulation and warming climate, leading to a heterogeneous pattern in the algal changes.

\section{Conclusion}

Our lake sediment records reveal a predominant effect of nutrient enrichment on phototrophic abundance in this shallow lake, as well as an increasing role of hydrological variability during the past few decades. Although fossil pigments appear to record a history of continuous fertilization, the replacement of eutrophic diatom species by small benthic taxa also suggests that anthropogenic water regulation, extreme droughts and warming have an influence on species composition. Such an interaction between nutrient and hydrological stressors is increasingly recognized (Vogt et al. 2018) and should be fully considered for reliable interpretation of paleoecological indicators and long-term ecosystem changes in shallow lakes. Finally, this study highlights the necessity of using multiple indicators for tracking primary production and phototrophic changes in shallow lakes. In particular, biological proxies (e.g. diatoms and pigments) have been increasingly and successfully applied in sediment-based studies to infer the temporal change of ecosystem structure in shallow systems, but they are often applied singularly without a full consideration of the differences in their sensitivity to multiple stressors for data interpretation which is evidenced in this work.

\section{$\underline{\text { Acknowledgements }}$}

This work was supported by the National Key Research and Development Program of China

删除的内容: paramoun [grant number 2017YFA0605202], National Natural Science Foundation of China [grant number 
1

2

362141171048 , U1133601], and Ministry of Education of China [grant number 213034A]. PRL and

4

$5^{622}$ IGE were supported by the Canada Research Chair program. We are grateful to Huibin Lu and

${ }_{7}^{6} 623$ Haibin Shi for their field work assistance, as well as Jiaoyuan Wang, Jianshuang Tao and

8624

12

13

14

15

16

17

18

19

20

21

22

23

24

25

26

27

28

29

30

31

32

33

34

35

36

37

38

39

40

41

42

43

44

45

46

47

48

49

50

51

52

53

54

55

56

57

58

59

60

61

62

63

64

65 


\section{References}

Adrian R, O'Reilly CM, Zagarese H, Baines SB, Hessen DO, Keller W, Livingstone DM, Sommaruga R, Straile D, Donk EV, Weyhenmeyer GA, Winder M (2009) Lakes as sentinels of climate change. Limnol Oceanogr 54:2283-2297.

Anderson JN (2000) Miniview: Diatoms, temperature and climatic change. Eur J Phycol 35:307314.

Appleby PG (2001) Chronostratigraphic techniques in recent sediments. In: Tracking environmental change using lake sediments. Volume 1: Basin analysis, coring and chronological techniques, (eds Smol JP, Birks HJB, Last WM) vol 1. Kluwer Academic Publishers, Dordrecht, The Netherlands, pp 171-203.

Barica J, Kling HJ, Gibson J (1980) Experimental Manipulation of Algal Bloom Composition by Nitrogen Addition. Can J Fish Aquat Sci 37:1175-1183.

Battarbee RW, Jones VJ, Flower RJ, Cameron NG, Bennion H (2001) Diatoms. In: Tracking Environmental Change Using Lake Sediments. Volume 3: Terrestrial, Algal, and Siliceous Indicators (eds Smol JP, Birks HJB, Last WM) vol 3. Kluwer Academic Publishers, Dordrecht, The Netherlands, pp 155-201.

Battarbee RW (2010) Foreword. In: Global Change Impacts on Mountain Lakes (eds Eggermont H, Kernan M, Martens K). Hydrobiologia 648:1-2.Beaulieu M, Pick F, Palmer M, Watson S, Winter J, Zurawell R, Gregory-Eaves I, Prairie Y (2014) Comparing predictive cyanobacterial models from temperate regions. Can J Fish Aquat Sci 71:1830-1839.

Bennion H, Rawcliffe R, Clarke G, Clarke SJ, Davidson TA, Rose C, Rose N, Sayer CD, Turner S (2009) Using novel palaeolimnological techniques to define lake conservation objectives. Final Report to Natural England. http://discovery.ucl.ac.uk/id/eprint/399621. 
Berthon V, Alric B, Rimet F, Perga M-E (2014) Sensitivity and responses of diatoms to climate warming in lakes heavily influenced by humans. Freshwater Biol 59:1755-1767.

Brugam RB, McKeever K, Kolesa L (1998) A diatom-inferred water depth reconstruction for an

Upper Peninsula, Michigan, lake. J Paleolimnol 20:267-276.

Bunting L, Leavitt PR, Gibson CE, McGee EJ (2007) Degradation of water quality in Lough Neagh, Northern Ireland, by diffuse nitrogen flux from a phosphorus-rich catchment. Limnol Oceanogr 52:354-369.

Byllaardt JV, Cyr H (2011) Does a warmer lake mean smaller benthic algae? Evidence against the importance of temperature-size relationships in natural systems. Oikos 120:162-169.

Carvalho L, Kirika A (2003) Changes in shallow lake functioning: response to climate change and nutrient reduction. Hydrobiologia 506-509:789-796.

Chen C, Zhao L, Zhu C, Wang J, Jiang J, Yang S (2014a) Response of diatom community in Lugu Lake (Yunnan-Guizhou Plateau, China) to climate change over the past century. J Paleolimnol 51:357-373.

Chen G, Selbie DT, Griffiths K, Sweetman JN, Botrel M, Taranu ZE, Knops S, Bondy J, Michelutti N, Smol JP, Gregory-Eaves I (2014b) Proximity to ice fields and lake depth as modulators of paleoclimate records: a regional study from southwest Yukon, Canada. J Paleolimnol 52:185-200.

Chen X, Yang X, Dong X, Liu E (2013) Environmental changes in Chaohu Lake (southeast, China) since the mid 20th century: The interactive impacts of nutrients, hydrology and climate. Limnologica 43:10-17.

Chen X, Yang X, Dong X, Liu Q (2011) Nutrient dynamics linked to hydrological condition and anthropogenic nutrient loading in Chaohu Lake (southeast China). Hydrobiologia 661:223-234. 
Chou G, Xia F (1998) Enhancing Environmental Management Promotes Water Quality in Yilong Lake. Yunnan Environ Sci 17:54-56.

Cuddington K, Leavitt PR (1999) An individual-based model of pigment flux in lakes: implications for organic biogeochemistry and paleoecology. Can J Fish Aquat Sci 56:1964-1977.

Cui B, Zhai H (2006) Characteristics of wetland functional degradation and its ecological water requirement for restoration in Yilong Lake of Yunnan Plateau. Chinese Sci Bull 51:127-135.

Dai A (2011) Drought under global warming: a review. Wiley Interdisciplinary Reviews: Clim Change 2:45-65.

Deng J, Qin B, Sarvala J, Salmaso N, Zhu G, Ventelä A-M, Zhang Y, Gao G, Nurminen L, Kirkkala T, Tarvainen M, Vuorio K (2016) Phytoplankton assemblages respond differently to climate warming and eutrophication: A case study from Pyhäjärvi and Taihu. J Great Lakes Res 42:386-396.

Digerfeldt G, Olsson S, Sandgren P (2000) Reconstruction of lake-level changes in lake Xinias, central Greece, during the last 40000 years. Palaeogeogr Palaeoclimatol Palaeoecol 158:65-82.

Finkel ZV, Vaillancourt CJ, Irwin AJ, Reavie ED, Smol JP (2009) Environmental control of diatom community size structure varies across aquatic ecosystems. Proc R Soc B 276:1627-1634. Hall RI, Leavitt PR (1999) Effects of agriculture, urbanization, and climate on water quality in the northern Great Plains. Limnol Oceanogr 44:739-756.

Hambright KD, Zohary T, Eckert W, Schwartz SS, Schelske CL, Laird KR, Leavitt PR (2008) Exploitation and destabilization of a warm, freshwater ecosystem through engineered hydrological change. Ecol Appl 18:1591-1603. 
Hayes, NM, A Patoine, HA Haig, GL Simpson, VJ Swarbrick, E Wiik, PR Leavitt (2019) Spatial and temporal variation in nitrogen fixation and its importance to phytoplankton in phosphorus-

Heiri O, Lotter F, Lemcke G (2001) Loss on ignition as a method for estimating organic and carbonate content in sediments: reproducibility and comparability of results. J Paleolimnol 25:101-110.

Hu Z, Li Y, Li S (2012) Spatial and temporal distributions of diatom communities and their relationships with environmental factors in Lake Erhai. J Lake Sci 24:400-408.

Huisman J, Matthijs HCP, Visser PM (2005) Harmful Cyanobacteria. Springer-Verlag GmbH, $3: 1-23$.

IPCC (2013) Synthesis Report. Contribution of Working Groups I , II and III to the Fourth Assessment Report of the Intergovernmental Panel on Climate Change. IPCC, Geneva, Switzerland.

Jarvis IAN, Gale AS, Jenkyns HC, Pearce MA (2006) Secular variation in Late Cretaceous carbon isotopes: a new $\delta^{13} \mathrm{C}$ carbonate reference curve for the Cenomanian-Campanian (99.670.6 Ma). Geol Mag 143:561-608.

Jeppesen E, Søndergaard M, Jensen JP, Havens KE, Anneville O, Carvalho L, Coveney M, Deneke R, Dokulil MT, Foy B, Gerdeaux D, Hampton SE, Hilt S, Kangur K, Köhler J, Lammens E, Lauridsen TL, Manca M, Miracle M, Moss B, Nõges P, Persson G, Phillips G, Portielje R, Romo S, Schelske CL, Straile D, Tatrai I, Willén E, Winder M (2005) Lake responses to reduced nutrient loading-an analysis of contemporary long-term data from 35 case studies. Freshwater Biol 50:1747-1771.Jin XC (1995) China Lake Environment (Volume 3). Haiyang Publishers, China, pp 263-273. 
Jöhnk KD, Huisman JEF, Sharples J, Sommeijer BEN, Visser PM, Stroom JM (2008) Summer heatwaves promote blooms of harmful cyanobacteria. Global Change Biol 14:495-512.

R-project.org/Package = rioja).

Kang W, Chen G, Wang J, Huang L, Wang L, Li R, Hu K, Liu Y, Tao J, Blais JM, Smol JP (2019) Assessing the impact of long-term changes in climate and atmospheric deposition on a shallow alpine lake from southeast Tibet. Sci Total Environ 650:713-724.

Krammer K, Lange-Bertalot H (1986-1991) Bacillariophyceae 1-4. In: Susswasserflora von Mitteleuropa, Band 1-4 (eds Ettl H, Gerloff J, Heynig H, Mollenhauer D). Gustav Fischer Verlag, Jena, Germany.

Lake SP (2011) Drought and Aquatic Ecosystems Effects and Responses. A John Wiley and Sons, Ltd., Publication.

Leavitt PR, Hodgson DA (2001) Sedimentary pigments. In: Tracking Environmental Change Using Lake Sediments. Volume 3: Terrestrial, Algal, and Siliceous Indicators (eds Smol JP, Birks HJB, Last WM) vol 3. Kluwer Academic Publishers, Dordrecht, The Netherlands, pp 295-325.

Leavitt PR, Brock CS, Ebel C, Patoine A (2006) Landscape-scale effects of urban nitrogen on a chain of freshwater lakes in central North America. Limnol Oceanogr 51:2262-2277.Lepš J, Šmilauer P (2003) Multivariate analysis of ecological data using CANOCO. Cambridge University Press, Cambridge, UK.

Ley S, Yu M, Li K, Tseng C, Chen C, Kao P, Huang F (1963) Limnological Survey of the lakes of Yunnan Plateau. Oceanol ET Limnol Sinica 5:87-114.

Li Y, Liu Y, Zhao L, Hastings A, Guo H (2015) Exploring change of internal nutrients cycling in a shallow lake: A dynamic nutrient driven phytoplankton model. Ecol Model 313:137-148. 
Liu Y, Chen G, Hu K, Shi H, Huang L, Chen X, Lu H, Zhao S, Chen L (2017) Biological

responses to recent eutrophication and hydrologic changes in Xingyun Lake, southwest China. J

Paleolimnol 57:343-60.

Maavara T, Parsons CT, Ridenour C, Stojanovic S, Durr HH, Powley HR, Van Cappellen P 15608.

Marc B, Falcão D, Marinho M, Pagano M, Moura A (2000) Occurrence of Cylindrospermopsis (Cyanobacteria) in 39 Brazilian tropical reservoirs during the 1998 drought. Aquatic Microbial Ecol 23:13-27.

McGowan S, Leavitt PR, Hall RI, Anderson NJ, Jeppesen E, Odgaard BV (2005) Controls of algal abundance and community composition during ecosystem state change. Ecology 86:22002211.Menking KM (1997) Climate signals in clay mineralogy and grain-size variations in Owens Lake core OI-92, eastern California. Special Paper of the Geol. Soc Am 317:25-36.

Meyer TJ (2001) Sediment organic matter. In: Tracking Environmental Change Using Lake Sediments. Volume 2: Physical and geochemical methods (eds Smol JP, Birks HJB, Last WM) vol 3. Kluwer Academic Publishers, Dordrecht, The Netherlands, pp 239-269.

Meyers PA, Ishiwatari R (1993) Lacustrine organic geochemistry - an overview of indicators of organic matter sources and diagenesis in lake sediments. Org Geochem 20:867-900.

Moorhouse HL, McGowan S, Jones MD, Barker P, Leavitt PR, Brayshaw SA, Haworth EY (2014) Contrasting effects of nutrients and climate on algal communities in two lakes in the Windermere catchment since the late 19th century. Freshwater Biol 59:2605-2620. 
Oksanen J, Blanchet FG, Kindt R, Legendre P, Min-Chin PBR, O'Hara RB, Simpson GL, Solymos P, Henry M, Stevens H (2015) vegan: Community Ecology Package (R package version

Peršić V, Horvatić J, Has-Schön E, Bogut I (2007) Changes in N and P limitation induced by water level fluctuations in Nature Park Kopački Rit (Croatia): nutrient enrichment bioassay. Aquat. Ecology 43:27-36.

Posch T, Köster O, Salcher MM, Pernthaler J (2012) Harmful filamentous cyanobacteria favoured by reduced water turnover with lake warming. Nature Climate Change 2:809-813.

R Team (2013) R: a language and environment for statistical computing. R Foundation for Statistical Computing, Vienna, Austria. ISBN 3-900051-07-0, URL http://www. R-project.org.

Reynolds CS (1987) The response of phytoplankton communities to changing lake environments. Swiss J Hydrol 49:220-236.

Reynolds CS (2006) Ecology of Phytoplankton (Ecology, Biodiversity and Conservation). Cambridge University Press, Cambridge, UK.

Romo S, Soria JM, Campo FFD, Benkaddour YO, Barón-Sola Á (2013) Water residence time and the dynamics of toxic cyanobacteria. Freshwater Biol 58:513-522.

Round F, Crawford R, Man D (2007) The diatoms biology and morphology of the genera. Cambridge University Press, Cambridge, UK.

Rühland K, Paterson AM, Smol JP (2008) Hemispheric-scale patterns of climate-related shifts in planktonic diatoms from North American and European lakes. Global Change Biol 14:27402754 . 
Rühland KM, Paterson AM, Smol JP (2015) Lake diatom responses to warming: reviewing the evidence. J Paleolimnol 54:1-35.

Saulnier-Talbot É, Gregory-Eaves I, Simpson KG, Efitre J, Nowlan TE, Taranu ZE, Chapman LJ (2014) Small Changes in Climate Can Profoundly Alter the Dynamics and Ecosystem Services of Tropical Crater Lakes. Plos One 9:e86561.

Scheffer MS, Hosper SH, Meijer ML, Moss B, Jeppesen E (1993) Alternative equilibria in shallow lakes. Trends Ecol Evol 8:275-279.

Scheffer M (1998) Ecology of Shallow Lakes. London, UK: Chapman and Hall

Schindler DW (2006) Recent advances in the understanding and management of eutrophication. Limnol Oceanogr 51:356-363.

Serruya C, Pollingher U (1977) Lowering of water level and algal biomassin Lake Kinneret. Hydrobiologia 54:73-80.

Shi L, Sun Q (2005) Brief Talk on Effect of Aquatic Plant Purifying Water body of Yilong Lake. Yunnan Environ Sci 24:40-42.

Shiping Yearbook (2005) Shiping Year Book (County Condification Committee). Yunnan Peoples's Publishing Press, pp 56-67, 169-173.

Smol JP, Wolfe AP, Birks HJ, Douglas MS, Jones VJ, Korhola A, Pienitz R, Ruhland K, Sorvari S, Antoniades D, Brooks SJ, Fallu MA, Hughes M, Keatley BE, Laing TE, Michelutti N, Nazarova L, Nyman M, Paterson AM, Perren B, Quinlan R, Rautio M, Saulnier-Talbot E, Siitonen S, Solovieva N, Weckstrom J (2005) Climate-driven regime shifts in the biological communities of arctic lakes. Proc Natl Acad Sci USA 102:4397-4402.

Smol JP (2010) The power of the past: using sediments to track the effects of multiple stressors on lake ecosystems. Freshwater Biol 55:43-59.Sommerfield C, Nittrouer C (1999) Modern 
accumulation rates and a sediment budget for the Eel shelf: a flood-dominated depositional environment. Mar Geol 154:227-241.

Søndergaard M, Jensen JP, Jeppesen E (2003) Role of sediment and internal loading of phosphorus in shallow lakes. Hydrobiologia 506:135-145. to The Biosphere. Princeton University Press, pp 439.

Stoermer EF, Smol JP (2001) The Diatoms: Applications for the environmental and earth science. Cambridge: Cambridge University Press. Cambridge: Cambridge University Press.

Taranu ZE, Zurawell RW, Pick F, Gregory-Eaves I (2012) Predicting cyanobacterial dynamics in the face of global change: the importance of scale and environmental context. Global Change Biol 18:3477-3490.

Taranu ZE, Gregory-Eaves I, Leavitt PR, Bunting L, Buchaca T, Catalan J, Domaizon I, Guilizzoni P, Lami A, McGowan S, Moorhouse H, Morabito G, Pick FR, Stevenson MA, Thompson PL, Vinebrooke RD (2015) Acceleration of cyanobacterial dominance in north temperate-subarctic lakes during the Anthropocene. Ecol Lett 18:375-384.

ter Braak CJF, Prentice IC (1988) A theory of gradient analysis. Adv Ecol Res 18:271-313.

ter Braak CJF, Šmilauer P (2002) CANOCO Reference Manual and CanoDraw for Windows User's Guide: Software for Canonical Community Ordination [Version 4.5]. Microcomputer Power, Ithaca, NY.

Tilman D (1987) Resource competition and community structure. Monographs in Population Biology. Princeton University Press 17:1-296. 
Vadeboncoeur Y, Jeppesen E, Zanden MJV, Schierup HH, Christoffersen K, Lodge DM (2003)

From Greenland to green lakes: Cultural eutrophication and the loss of benthic pathways in lakes. Limnol Oceanogr 48:1408-141.

Vogt RJ, Sharma S, Leavitt PR (2018) Direct and interactive effects of climate, meteorology, Prairies. Can J Fish Aquat Sci 75:47-59.

Wagner C, Adrian R (2009) Cyanobacteria dominance: Quantifying the effects of climate chang. Limnol Oceanogr 54:2460-2468.

Wang H, Yang Z, Wang L, Liu Y, Song Y, Gao J (2014) The application of TVDI in drought monitoring over Yunnan province during 2009 to 2010. J. Yunnan University (Sci.) 36:59-65.

Wang J, Chen G, Kang W, Hu K, Wang L (2019) Impoundment intensity determines temporal patterns of hydrological fluctuation, carbon cycling and algal succession in a dammed lake of

Southwest China. Water Res 148:162-75.

Wang W, Wang L (2008) Current situation of agricultural non-point source pollution and Control Countermeasures in Yilong lake. Yunnan Agricultural Science and Technology, pp 139-141.

Wang Z (1997) Survey of zooplankton and fish productivity in Yilong Lake, Yunnan. J. Fisheries China 402-407.

Wieland E, Santschi P, Höhener P, Sturm M (1993) Scavenging of Chernobyl ${ }^{137}$ Cs and natural ${ }^{210} \mathrm{~Pb}$ in Lake Sempach, Switzerland. Geochimica Et Cosmochimica Acta 57:2959-2979.

Winder M, Hunter DA (2008) Temporal organization of phytoplankton communities linked to physical forcing. Oecologia 156:179-192.

Wu F, Zheng M, Hu G (2016) The Estimation of Vegetation Coverage of Yanshan County in Yunnan by Remote Sensing Based on OLI Data. Environ Sci Survey 36:5-7. 
Wu J, Jiang X, Xia W, Pan H, Yin Y (2002) Climate and Primary Productivity over the last 500 years of the Chenghai Lake,Yunnan. Mar Geol Quaternary Geol 22:95-98.

Xie L, Xie P, Li S, Tang H, Liu H (2003) The low TN:TP ratio, a cause or a result of Microcystis blooms? Water Res 37:2073-2080. phytoplankton growth in eutrophic lake Taihu, China. Limnol Oceanogr 55:420-432.

Xu J, Wen Z, Ke Z, Zhang M, Zhang M, Guo N, Hansson LA, Xie P (2014) Contrasting energy pathways at the community level as a consequence of regime shifts. Oecologia 175:231-241.

Xu M, Chang CP, Fu CB, Qi Y, Robock A, Robinson D, Zhang HM (2006) Steady decline of east Asian monsoon winds, 1969-2000: Evidence from direct ground measurements of wind speed. J Geophy Res 111: 1-8.

Yang L, Li H, (2010) Wetlands of Yunnan. China Forestry Publishing House, pp 94-101.

Yang X, Lu X (2014) Drastic change in China's lakes and reservoirs over the past decades. Sci Rep 4:6041.

Zhang J, Wang Z, Song Z, Xie Z, Li L, Song L (2012) Bioaccumulation of microcystins in two freshwater gastropods from a cyanobacteria-bloom plateau lake, Lake Dianchi. Environ Pollut $164: 227-34$.

Zhang Y, zhang E, Liu M (2009) Spectral absorption properties of chromophoric dissolved organic matter and particulate matter in Yunnan Plateau lakes. J Lake Sci 21:255-263.

Zhao L (2013) The regime shifts and inversion of catastrophic driving factors in the ecosystems of Yilong Lake, Yunnan. Dissertation, University of Chinese Academy of Science. 
1

2

$3^{872}$ Zhao L, Li Y, Zou R, He B, Zhu X, Liu Y, Wang J, Zhu Y (2013) A three-dimensional water

4

$5^{873}$ quality modeling approach for exploring the eutrophication responses to load reduction scenarios 6874 in Lake Yilong (China). Environ Pollut 177:13-21.

\section{7}

8

9 
$3^{875}$ Table 1 Summary of key limnological features of Yilong Lake

$4 \quad$ Variable Value

$5 \quad$ Altitude $(\mathrm{m})^{\mathrm{a}} \quad 1,413.4$

$7 \quad$ Lake surface area $\left(\mathrm{km}^{2}\right)^{\mathrm{a}} \quad 34.0$

8 Catchment area $\left(\mathrm{km}^{2}\right)^{\mathrm{a}} \quad 326.0$

$10 \quad$ Average water depth $(\mathrm{m})^{\mathrm{a}} \quad 2.9$

11 Max. water depth (m) ${ }^{\mathrm{a}} \quad 3.7$

$12 \quad$ Chlorophyll $(\mu \mathrm{g} / \mathrm{l})^{\mathrm{b}} \quad 214.3$

13 Transparency $(\mathrm{m})^{\mathrm{b}} \quad 0.1$

$15 \mathrm{TN}(\mathrm{mg} / \mathrm{l})^{\mathrm{b}} \quad 7.7$

$16 \mathrm{TP}(\mu \mathrm{g} / \mathrm{l})^{\mathrm{b}} \quad 123.3$

$\begin{array}{ll}17 & \mathrm{pH}^{\mathrm{b}} \\ 18 & 8.8\end{array}$

$19876 \quad{ }^{a}$ Data are from Yang \& Li (2010).

$20_{877 \quad \text { b }}$ Data were collected in the summer of 2013 from the current study. 
Table 2 Monitored changes of algae abundance, lake-water N:P mass ratio and macrophyte coverage over time in Yilong Lake

\begin{tabular}{|c|c|c|c|c|c|c|c|}
\hline Year & $\begin{array}{l}\text { Cyanobacteria } \\
\left(10^{6} \text { cell/1) }\right.\end{array}$ & $\begin{array}{c}\text { Diatoms } \\
\left(10^{6} \mathrm{cell} / \mathrm{l}\right)\end{array}$ & $\begin{array}{l}\text { Phytoplankton } \\
\left(10^{6} \text { cell } / 1\right)\end{array}$ & Dominant algae & $\begin{array}{c}\text { Cyanobacteria } \\
(\%)\end{array}$ & $\begin{array}{l}\mathrm{N}: \mathrm{P} \text { ratio } \\
\text { (by mass) }\end{array}$ & $\begin{array}{l}\text { Macrophyte } \\
\text { coverage (\%) }\end{array}$ \\
\hline 1957 & & & $8.41^{\mathrm{a}}$ & $\begin{array}{l}\text { Bacillariophyta (except episodic } \\
\text { cyanobacteria bloom in Aug.) }\end{array}$ & & & \\
\hline 1982 & & & & & & 14.39 & $95.0^{\mathrm{d}}$ \\
\hline 1988 & & & $46.00^{\mathrm{b}}$ & $\begin{array}{c}\text { Chlorophyta } \\
\text { (Pediastrum simplex) }\end{array}$ & & 89.23 & \\
\hline 1992 & $180.47^{\mathrm{c}}$ & $4.00^{\mathrm{c}}$ & $193.21^{\mathrm{c}}$ & $\begin{array}{c}\text { Cyanobacteria } \\
\text { (Aphanizomenon flosaquae) }\end{array}$ & $93.41^{\mathrm{c}}$ & 82.95 & $27.3^{\mathrm{e}}$ \\
\hline 1993 & & & $50.88^{\mathrm{d}}$ & $\begin{array}{c}\text { Chlorophyta } \\
\text { (Pediastrum simplex) }\end{array}$ & & 73.84 & \\
\hline 1997 & $19.76^{\mathrm{e}}$ & $0.21^{\mathrm{e}}$ & $21.78^{\mathrm{e}}$ & $\begin{array}{c}\text { Cyanobacteria } \\
\text { (Microcystis aeruginosa) }\end{array}$ & $90.75^{\mathrm{e}}$ & 38.28 & $40.0^{\mathrm{e}}$ \\
\hline 2008 & $82.30^{\mathrm{f}}$ & $1.31^{\mathrm{f}}$ & $88.51^{\mathrm{f}}$ & $\begin{array}{c}\text { Cyanobacteria } \\
\text { (Microcystis aeruginosa) }\end{array}$ & $92.98^{\mathrm{f}}$ & 49.65 & $60.0^{\mathrm{e}}$ \\
\hline 2010 & & & $317.20^{\mathrm{e}}$ & $\begin{array}{c}\text { Cyanobacteria } \\
\text { (Cylindrospermopsis raciborskii) }\end{array}$ & 99.00 & 40.33 & $<10.0^{\mathrm{e}}$ \\
\hline 2015 & 244.65 & 0.59 & 248.14 & $\begin{array}{c}\text { Cyanobacteria } \\
\text { (Aphanizomenon flosaquae) }\end{array}$ & 98.59 & 51.20 & \\
\hline
\end{tabular}

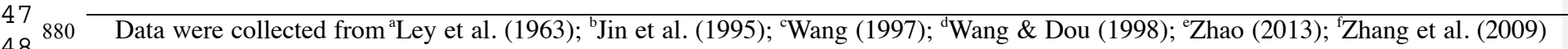

49

50

51 
Table 3 Summary of individual RDAs for key environmental variables in accounting for the variance (adjusted $\mathrm{R}^{2}$ ) in the algal production and diatom PC1 score during the periods of $\sim 1903$ -

5

6

7

2013 and $\sim 1953-2013$, respectively

\begin{tabular}{lllll}
\hline \multirow{2}{*}{ Environmental Variable } & \multicolumn{2}{c}{ Pigments } & \multicolumn{2}{c}{ Diatom PC1 } \\
& $1903-2013$ & $1953-2013$ & $1903-2013$ & $1953-2013$ \\
\hline Median grain size $(\mu \mathrm{m})$ & -0.027 & -0.034 & -0.023 & -0.024 \\
Clay $(\%)$ & -0.027 & -0.033 & -0.022 & -0.019 \\
Silt $(\%)$ & -0.024 & -0.016 & -0.016 & 0.007 \\
Sand $(\%)$ & 0.034 & $0.197 * *$ & 0.047 & $0.273 * * *$ \\
$\delta^{13} \mathrm{C}(\%)$ & 0.094 & $0.419 * * *$ & -0.022 & -0.017 \\
$\delta^{15} \mathrm{~N}(\%)$ & $0.217 * *$ & $0.783 * * *$ & 0.038 & $0.224 * * *$ \\
$\mathrm{C} / \mathrm{N}$ ratio & $0.233 * *$ & $0.846 * * *$ & 0.034 & $0.189 * * *$ \\
$\mathrm{TC}(\mathrm{mg} / \mathrm{g})$ & $0.786 * * *$ & $0.796 * * *$ & $0.324 * * *$ & $0.103 *$ \\
$\mathrm{TN}(\mathrm{mg} / \mathrm{g})$ & $0.900 * * *$ & $0.824 * * *$ & $0.406 * * *$ & $0.159 * * *$ \\
Population & - & $0.822 * * *$ & - & $0.121 * *$ \\
Temperature $\left({ }^{\circ} \mathrm{C}\right)$ & - & $0.288 * * *$ & - & $0.233 * * *$ \\
Precipitation $(\mathrm{mm})$ & - & -0.020 & - & 0.044 \\
Wind speed $(\mathrm{m} / \mathrm{s})$ & - & $0.384 * * *$ & - & -0.009 \\
All variables & $0.914 * * *$ & $0.912 * * *$ & $0.270 * * *$ & $0.136 * *$ \\
\hline
\end{tabular}

Significance codes for $P$-level: “***’, $P<0.001$; ‘**’, $P<0.01$; “*’, $P<0.05$.

Note: An adjusted $R^{2}$ near 0 indicates that the environmental variable does not explain more of the variation of the biotic assemblages change than random normal variable would do; Negative adjusted $\mathrm{R}^{2}$ indicates that the explanatory variables perform similarly as random normal variables would. 